DOI: $10.52837 / 27382702-2021-34.1-22$

\title{
THE NEW KINGDOM OF EGYPT AND THE EARLY STATE ORGANIZATIONS OF THE ARMENIAN HIGHLAND IN THE SECOND HALF OF THE II MILLENNIUM BC (BASED ON HISTORICAL SOURCES AND ARCHAEOLOGICAL EVIDENCE)*
}

\author{
Ashot Piliposyan, Armine Hayrapetyan
}

\begin{abstract}
The Ancient Near Eastern powerful states in the mid II millennium BC were not only directing and supervising the military-political, trading-economic, and sociocultural processes, but were also trying to obtain their dominance and control in the region. This was the reason that two conflicting groups gradually polarized in the region, where each state, despite its interests concerning the redistribution of spheres of influence in the ancient Near East, had to ally a more convenient political formation, given the current political situation and its capacities. As a result, the Hittite New Kingdom, Arzawa and Wilusa appeared to be in one of the groups, and the New Kingdom of Egypt, Kassite Babylonia and Mitanni were in the other one. The interstate relations of these powers included both military-political and diplomatic rivalry, and a controlled system of well-organized transit trading and cultural relations. At the same time, each of the groups sought to urge other small early state organizations and tribal unions of the region to get involved in the alliance, contributing to the realization of prospective political plans with their capacities of raw materials, production of specific items and human resources. This was the situation also with the part of the early state organization of the Armenian Highland. Meanwhile, both the written sources and the archaeological excavations in general, testify the anti-Hittite orientation of the early state organizations of the Armenian Highland and their tending towards Egypt-Mitanni-Kassite Babylonia alliance.
\end{abstract}

Keywords: Armenian Highland, New Kingdom of Egypt, Mitanni, Kassite Babylonia, Early state organizations, Nairi, Etiuni, archaeology.

\footnotetext{
* The article was submitted on June 21, 2021: The article was reviewed on June 26, 2021.
} 
The Ancient Near East as well as the Mediterranean basin were the arena of tumultuous developments in the mid II millennium BC. The periodically recurring adverse natural and climatic phenomena (everlasting droughts, earthquakes, epidemics, floods, frosts, etc.), the active ethnic movements (the expulsion of the Hyksos from Egypt, the wanderings of the Sea peoples in the Eastern Mediterranean and their establishment in its various parts, the entry of the Kassites into Babylon, etc.), the internal contradictions and inter-state conflicts of the local powerful states, as well as various other processes, had significantly changed the vivid ethno-political pattern of the region ${ }^{1}$. The new states formed in the result of these developments (the New kingdom of Egypt and the Hittite empire, Kassite Babylonia, Mitanni) having overcome the longlasting crisis, where not only directing and supervising the military-political, trading-economic, and socio-cultural processes, but were also trying to obtain their dominance and control in the region.

Apparently, this was the reason that two conflicting groups were gradually polarized in the region, where each state, despite its interests concerning the redistribution of spheres of influence in the ancient Near East, had to ally a more convenient political formation, given the current political situation and its capacities. As a result, the new Hittite Kingdom, Arzawa and Wilusa (llionTroy) appeared to be in one of the groups, and the New Kingdom of Egypt, Kassite Babylonia, and Mitanni (Naharina) were in the other ${ }^{2}$. The inter-state relations of these powers included both military-political and diplomatic rivalry (mainly to achieve dominance upon the territory of Levant), and a controlled system of well-organized transit trading and cultural relations. The latter was mainly realized through the maritime city of Ugarit, which since the fall of karum Kanish (Kanesh) trading center $\left(19^{\text {th }}-18^{\text {th }} \mathrm{Cc}\right.$. BC), especially by the $15^{\text {th }}$ $13^{\text {th }} \mathrm{cc}$. BC had obtained a monopolistic position over the western transit trading route of the Near East ${ }^{3}$. At the same time, each of the groups sought to

${ }^{1}$ Grayson 1975: text № 21; IDV 1983: 420-421; Yakobson 1989: 198-199; Kosyan 1999: 8-16; Kuzishchin 2007: 48-64; Nikol'skaya, Kločkov, Tomaševič, Tkačenko 2008: 178.

2 Chernykh 1989: 24-25.

${ }^{3}$ Martirosyan 1971: 219; Shifman 1987: 126-142. 
urge the other small early state organizations and tribal unions of the region to get involved into the alliance, contributing to the realization of prospective political plans with their capacities of raw materials, production of specific items and human resources. This was the situation also with the part of the early state organizations of the Armenian Highland (Hayasa-Azzi, TegaramaTogarma, Alzi-Alshe, Nairi-Nikh(i)ria, and probably Etiuni) ${ }^{4}$. Meanwhile, both the written sources ${ }^{5}$ and the archaeological excavations ${ }^{6}$ in general, testify the anti-Hittite orientation of the early state organizations of the Armenian Highland and their tending towards Egypt-Mitanni-Kassite Babylonia alliance. The data on the Togarma-Hittite, Hittite-Hayasa, Nairi-Assyrian and MitanniEtiuni (Ayrarat) relations were widely discussed in the special literature ${ }^{7}$. For

${ }^{4}$ Indeed, as an early state organization, Etiuni is mentioned for the first time since the late $9^{\text {th }} \mathrm{C}$. BC. Therefore, its inclusion in the list of the abovementioned "countries" is problematic at first sight. Nevertheless, the pattern of the historical-cultural realities of the $16^{\text {th }} / 15^{\text {th }}-10^{\text {th }} / 9^{\text {th }} \mathrm{cc}$. BC reconstructed due to the excavations of the Middle Bronze, Late Brozne and Early Iron Age sites of the central regions of the Armenian Highland (the territory of Kars, the Ararat Valley, Shirak, Gugark, Aragatsotn, Syunik, Goghtn, Masyatsotn) represents generalized processes of the uniform development of local societies, gradual rapprochement, development of identical forms of government, similar organization of landscape and living space, as well as lifestyle, establishment of equal moral standards, formation of similar spiritual and religious perceptions, and identical manifestation of material culture. The mentioned situation could be developed in the conditions of early state organizations and/or tribal confederations that co-existed side by side, faced similar socio-economic challenges, anticipated targeted and prospective common development, and possessed with certain levels of governance and control. The name of that formation in the mid-2 $2^{\text {nd }}$ mill. BC is yet unknown, but since the late $9^{\text {th }} \mathrm{C}$. BC its territory was called Etiuni, according to the Urartian inscriptions. Therefore, taking into account the abovementioned, we are inclined to believe that the latter could be the initial stage of the same formation, and its origins, apparently goes back to the $17^{\text {th }}-16^{\text {th }}$ centuries BC (Khanzadyan 1982: 37; Piliposyan 2000: 43-44).

${ }^{5}$ Khachatryan 1971: 19-23, 94-96, 130-132, 138-145; Diakonoff 1968: 210-211; Kapantsyan 1947: 22-60, 236-244; Kosyan 2004: 108-156.

${ }^{6}$ Piliposyan 1998: 42-44; Piliposyan, Hovhannisyan 2003: 72-82; Piliposyan 2007: 41-52; Piliposyan 2010: 203-222; Mkrtchyan, Piliposyan 2011: 250-263; Piliposyan, Zakyan, Gevorgyan, Poghosyan 2013; Piliposyan 2014: 99-107: Piliposyan 2015: 52-72; Piliposyan 2018: 114-125:

7 Kapantsyan 1947: 37; Korostovtsev 1978: 112, 119, 124, 289; Macqueen 1983: 41-42; Gurney 1987: 28-33; Avetisyan 1984: 45; Khachatryan 1971: 128-145; IDV II 1988: 144-150; Deller, Fadhil, Ahmad 1994, 461-467; Kosyan 1997; Kosyan 1998; Kosyan 1999, Tsakanyan 2017: 161-172. 
Mitanni, in particular, the mentioned developments are proved by the discoveries of Mitannian cylindrical seals ${ }^{8}$ from the archaeological complexes of the $15^{\text {th }}-14^{\text {th }}$ Cc. BC (Lchashen, Artik, Aradjadzor, Metsamor, Aruch, Harich, Lori Berd, Qanagegh, Gegharot), that had been sent to the leaders of the early state organizations of the Armenian Highland by the Mitannian rulers and high-ranked officials. As for the Kassite Babylonia, the discovery of royal symbols (a frog-shaped weigh made of sardonyx with a cuneiform inscription, an inscribed cylindrical seal made of agate) in Metsamor, represented personal property of the powerful rulers of the country (Ulam-Buriash, the Son of Burna-Buriash $\mathrm{I}^{9}$, and Kurigalzu I), also points at business affairs of the latter with the rulers of an early state organization (probably, Etiuni) of the Armenian Highland. The consideration of these facts allows to conclude that some of the $16^{\text {th }}-14^{\text {th }}$ cc. BC early state organizations of the Armenian Highland, in the complex military-political conditions formed in the region by the mid- $2^{\text {nd }}$ mill. BC, were not only involved in the military-political alliance of the Egypt-Mitanni-Kassite Babylonia, but had also taken clear anti-Hittite measures, which allowed to obtain various goods and raw materials of strategic importance (gold, tin, seashells, etc.) from the allies. In this context, the relationship between the Armenian Highland and the New Kingdom of Egypt was discussed relatively little (see below).

The matter is that due to the efforts of the first pharaohs of the $18^{\text {th }}$ dynasty (1552-1305 BC) the New Kingdom of Egypt had expelled the Hyksos from the country and, expanding the borders, had spread its influence also over the Palestine and the Northern Mesopotamia ${ }^{10}$, coming close to the Taurus Mountains, the southern reaches of the Armenian Highland. For these rulers of Egypt, the position and attitude of the local early state organizations

\footnotetext{
${ }^{8}$ Piliposyan 1998, 42:

9 IDV I 1983: 420-421; Bertman 2007: 99-100, 124-125; Khanzadian, Sarkisian, Diakonoff 1992: 75-83.

10 This is especially true of Thutmose III, who during his reign organized 17 victorious campaigns in Palestine and Northern Mesopotamia, conquered and turned into his ally Mitanni, and then reached the middle course of the Euphrates River. https://www.ucl.ac.uk/museumsstatic/digitalegypt/chronology/thutmosisiii.html; Aldred 2004: 122.
} 
would certainly matter. Therefore, it is possible that particular steps would be taken to solve those issues at this stage. Judging from the artifacts of the Egyptian origin found in different parts of the Armenian Highland, such contacts and relations really took place. They were of a practical nature and, apparently, formed mutually acceptable approaches to the complex situation in the region. So far, in order to identify the issues around which the parties could negotiate and come to a common understanding, then, judging by the written and archaeological sources, they would most likely include the following sub-items:

Recognition of local early state organizations' authorities as strategic partners and involvement of the latter in anti-Hittite activities;

The inclusion of some of the early state organizations of the Armenian Highland in the general measurement system of Egypt and its allies;

The establishment of trade, economic and cultural ties that are of utmost importance for both sides to that date.

The first point mentioned is proved by the important archaeological finds of the $15^{\text {th }}-14^{\text {th }}$ cc. BC that were discovered in the burial complexes of high social rank, as well as the excavations of most powerful and organized settlements of the Armenian Highland at this period. In this regard, the scarab-seals, discovered from the ancient settlement of Metsamor are of paramount importance, since they are directly related to the reign of the pharaohs of the $18^{\text {th }}$ dynasty of Egypt.

The first scarab-seal was uncovered in the vicinity of the fourth counterfort in the eastern part of the Metsamor citadel rampart. It has a hemispherical body and a smooth stamping surface, bearing a personal name $^{11}$ in Egyptian hieroglyphs imbedded in a deep ellipsoid royal cartouche, with the hieroglyph of "feather of truth" in the right part (Tab. I, fig. 1) that can be found very often on the seals of that period ${ }^{12}$. The seal was made of

${ }^{11}$ Piliposyan, Zakyan, Gevorgyan, Poghosyan 2013: 19; Piliposyan 2015: 56.

12 Khodjash 1999: 83-86, № 326-328. 
steatite $^{13}$ and was covered in turquoise glaze, the traces of which are still visible in the deep engravings of the hieroglyphs. Some orientalists have tried to read the name of the ruler of Egypt Tuthmose III (1479-1425 BC). In fact, the throne name of Tuthmose III "Menkheperre" was inscribed in Egyptian hieroglyphic texts, as well as the scarab-seals and pendants with a circular Sun symbol or an ovoid symbol, a Senet board symbol (here sand hills with pointed summits) and the sacred scarab hieroglyphs (Tab. I, fig. 2-13) ${ }^{14}$. The Metsamor scarab-seal contains these hieroglyphs on the sealing side and apparently should be read as the "Menkheperre", the throne name of Tuthmose III. The Metsamor scarab-seal repeats the stylistics of the scarabs with the names of the $18^{\text {th }}$ dynasty pharaohs of Egypt and should most probably be related to the $15^{\text {th }} \mathrm{c}$. BC, to the period of the reign of Tuthmose III or later.

The second scarab-seal (Tab. I, fig. 14) was found during the excavations of the burial no. 17. It was made of fine kaolin clay, fired and covered with greenish-turquoise glaze, which is preserved on the surface in residual form. It has a hemispherical body and a flat, ovoid sealing surface. The latter bears a cartouche encircling a falcon on the pedestal (the symbol of Horus), with a scepter or a flail on his back and in the lower part a crescent or a boat ${ }^{15}$. Interestingly, the images of a whip and a boat are more frequent in the titles of the $18^{\text {th }}$ dynasty pharaohs ${ }^{16}$ (Tab. I, fig. 15-23). In the meantime, the hieroglyphic symbol of a falcon perched above a pedestal is deciphered as "Golden Horus name" and is considered as one of the five most important titles of the pharaoh. In particular, Tuthmose III, while talking of this title tells: "He (i.e., Amun) created me as a "bjk n nbw" - a Golden Falcon"17. The mentioned aspects directly point at the fact that both the scepter "Uas-

\footnotetext{
${ }^{13}$ In our earlier publications we had mentioned that the seal was made of the finely seaved clay, but later investigations by geologists have proven its being made of steatite.

${ }^{14}$ Khodjash 1976: 85-113, tab. I-IV; Piliposyan, Hovhannisyan 2003: 75-76, tab. 4.

${ }^{15}$ Bonewitz 2003: 160, 168; Boonstra 2019: 154-156.

${ }^{16}$ Khodjash 1976: tab. I-IV; Khodjash 1999: 87, № 358.

${ }^{17}$ Helck, Otto 1999: 153; Allen 2000: 64-66.
} 
scepter" and the flail "nekhakha" symbolized supreme power in Egypt. ${ }^{18}$ So far, we can assume that the scarab-seal uncovered from the burial no. 17 should also be related to the $18^{\text {th }}$ dynasty of Egypt. The archaeological materials uncovered in this burial also refer to the same period $\left(14^{\text {th }}-13^{\text {th }} \mathrm{cc}\right.$. $\mathrm{BC})^{19}$. It is possible that an Egyptian official handed the scarab to the person buried in the burial no. 17 of Metsamor on special purpose (recognition of power, advanced trade and economic ties, military support, etc.), expecting cooperation and fulfillment of certain allied obligations.

This cooperation continued also until the end of the New Kingdom of Egypt, during the reign of the pharaohs of the $20^{\text {th }}$ dynasty. This is testified by the finds of scarab pendants uncovered from burials nos. 1, 18, 34 and 106 $\left(12^{\text {th }}-11^{\text {th }}\right.$ Cc. BC) of the Horom cemetery (Tab. II, fig. 1). They were made of bitumen and covered with thin gold foil on the upper part ${ }^{20}$. Close to the seal base, which was not gold-plated, two lateral reach-through holes were made for incorporating the pendant into a necklace, as made on the $15^{\text {th }}-12^{\text {th }} \mathrm{cc}$. BC Egyptian samples (Tab. II, fig. 2-8 $)^{21}$.

The golden foil fragments uncovered in the burial no. 1 allow us to assume that they belong to at least three similar scarab-pendants. The biggest foil fragment allows to reconstruct the whole decoration of the gold-plating. Two deep vertical lines split the surface into three equal parts, each covered with fine deep and dense oblique lines. The preserved edge of the foil fragment is decorated with a belt of oblique lines enclosed in two parallel grooves. The paleoanthropological materials of the burial testify its belonging to a man of 40-45 years old 22 .

\footnotetext{
${ }^{18}$ Badge 2000: 227-231; Lurker 1998: 134-137.

19 They are still kept at the storage of the Historical-archaeological museum-reserve of "Metsamor" and are not yet published.

${ }^{20}$ Piliposyan, Badalyan 2007: 130-133, Tabl. LXXIII-2.

${ }^{21}$ Hassaan 2017: 21, fig 5; Tour Egypt 2017 http://www.touregypt.net/featurestories/picture 05182004.htm, https://glencairnmuseum.org/newsletter/2020/3/6/sacred-adornment-jewelryas-belief-in-ancient-egypt

22 The studies of sex and age definitions of the anthropological materials were realized by the anthropologist, Associate Professor Ruzan Mkrtchyan, Ph.D.
} 
The excavations of the burial no. 18 revealed three scarab-pendants made of bitumen, although the foil-covers where not found. There was a skeleton of a 40-50 years old male.

The discovery of gilding foil fragments from the burial no. 34 allows us to assume that two (or more) scarab-pendants should be buried here. Fine engravings on the preserved surfaces mainly repeat the ornaments of similar materials from the Horom burial no. 1. They belonged to a man of mature age.

At least five scarab-pendants were buried in the tomb no. 106, judging by the fragments of gilding foil. Their decorations represent different motives. Two dotted lines divided the whole surface into three horizontal sections, the first of which was the head of the scarab, the second one was the body (pronotum) and the third one was the lower body part (elytron). The head was decorated with the dotted crosshatching, the middle part-pronotum is covered with deeply engraved hatching net and the elytron part is decorated with a vertical dotted line, separating the surface into two dotted triangles, which looks like the lower part of the beetle's wings. Remains of a 45-55-year-old female were uncovered in the burial ${ }^{23}$.

Only four relatively rich burials out of 160 excavated ones at Horom cemetery yielded similar objects. This fact allows us to assume that scarabpendants were not accessible to everyone at this period; these objects belonged to the elderly representatives of the local Early Iron Age society elite, as symbols of power and position, and most probably apart from the high status and occupation they signified also the connection of their owners to the high-ranked officials or even the palace of the New Kingdom of Egypt.

These ties and relations are indirectly confirmed by another reality as well. This was the inclusion of some of the early state organizations of the Armenian Highland in the general measurement system of Egypt and its allies, which meant the regulation of general trading activities, the assortment to be sold, transit routes, customs duties and other issues. The most important fact

${ }^{23}$ Mkrtchyan 2001: 110. 
in support of this proposal is the frog-shaped weigh found in the Metsamor burial no. 8. It is made of sardonyx and bears a Middle Assyrian cuneiform inscription of Ulam-Buriash, the Son of Burna-Buriash I, the king of Kassite Babylonia $^{24}$. In particular, it directly indicates on the inclusion of the Ararat Plain (Etiuni) rulers in the measurement system of Egypt-Mitanni, Kassite Babylonia alliance ${ }^{25}$. Since this period, the number of golden objects abruptly increases in the high social rank burial complexes of the Late Bronze Age local settled societies. It is possible that in return to the engagement in anti-Hittite activities, some early state organizations of the Armenian Highland, like other Near Eastern powers of an anti-Hittite orientation, had obtained the right to the shares of gold from the Egyptian Behen (Coptos) and Nubian (Kush and Wawat) mines and thereby had made their allied obligations firmer and more practical $^{26}$.

Another notable evidence of the establishment of trade, economic and cultural relations between the New Kingdom of Egypt and the early state organization of the Ararat Valley (Etiuni) consists of luxury items made of cornelian and agate, which were uncovered in the Metsamor Late Bronze Age burials (already partially robbed in antiquity) (Tab. III, fig. 1, 3, 4). Their direct parallels which were found in Egypt (Tab. III, fig. 5-8, 11-15), in the opinion of the investigators consisted of beads in the form of symbolic puppies, which were braided in the necklaces, dedicated to the elite and were worn over their clothes. Most probably, in addition to the aesthetic appearance, the latters were also attributed symbolic meaning and significance.

In the Near East, the Mediterranean Basin, and North Africa, the seeds of this plant, and especially the capsules, were widely distributed and were in

\footnotetext{
${ }^{24}$ Khanzadyan, Sarkisyan, Diakonoff 1983: 118.

25 Piliposyan 2014: 100-107.

${ }^{26}$ Piotrovskiy 1983: 14, 17-20; Montet 1989: 139-141, 147-151.
} 
large demand. They were not only used in the food, applied as a painkiller remedy, but also were source of psychotropic drugs ${ }^{27}$.

The pomace, tincture, and the gum, as well as the psychotropic effects of the latter on humans were known in the region since very remote times ${ }^{28}$. The earliest records on this matter are known from the Sumerian and Assyrian texts $^{29}$. Later mentions come from the Classical historians (Hesiod, Homer, Theophrastus, Diodorus Siculus, Hippocrates, Aristotle, Diagoras, Pliny the Elder etc.) as well as the ancient legends of the region (in particular, the legend of the Argonauts) ${ }^{30}$. It is possible that already in the Middle and Late Bronze Ages the local priests were using it during some rituals to reach hallucination or state of ecstasy and in clairvoyance practices. It justifies the use of poppy capsules as symbolic objects, their duplication and imitation in various materials (gold, agate, cornelian, Lapis Lazuli, glazed clay, glass etc.) and wearing as specific ritual amulets.

Orientalists consider the Asia Minor, Armenian Highland, Greece, Iranian plateau and rarely North-Eastern Africa (Egypt) as possible areas of preliminary cultivation of poppies ${ }^{31}$. In regard to North-Eastern Africa, an opinion prevails concerning the occasional use of poppies in the early period (the $3^{\text {rd }}$ mill. $\mathrm{BC}$ ), and its spread which began since the $2^{\text {nd }}$ mill. $\mathrm{BC}$ and was mostly related to the activities of the representatives of the $18^{\text {th }}$ dynasty ${ }^{32}$. The sedative and analgesic means, as well as psychotropic drugs made of this plant

${ }^{27}$ Goltsman 2000: 6, 327-328; Tomashevska 2019: 43-44

https://www.researchgate.net/publication/337547952

${ }^{28}$ Merelin 2003: 295-323.

${ }^{29}$ Thompson 1924: 46, 251, 261, 269; Terry, Pellens 1928: 54; Anslinger, Tompkins 1953: 1; Kramer 1954: 76-84.

${ }^{30}$ Kritikos, Papadaki 1967: 17-38; Grinkevich, Sorokina 1988: 9-12.

31 Tschirch 1923: 647; Gabra 1956: 41-42, fig. 1-4; Merrillees 1962: 287- 292; Niggorski 1999: 537-542; Arnott 1999: 268-271; Manniche 1999: 26-34; Julyan, Dircksen 2011: 75-90.

32 In any case, the detailed medical examination of the mummy of the Chief palace builder Hay of the son and successor of Thutmose III - Amenhotep II (1428-1397 BC) did not reveal any trace of a psychotropic drug (in particular, opium) which indicates on its low distribution and moreover its application in the $15^{\text {th }}$ c. BC (Muzzio 1925: 249-253; Bisset, Bruhn, Curto, Holmstedt, Nyman, Zenk 1994: 99-114; Bisset, Bruhn, Curto, Holmstedt, Nyman, Zenk 1996: 200). 
started to spread in Egypt since this period. There is also an opinion that the initial samples of this plant and/or the products made of it were imported from Cyprus, Asia Minor or adjacent territories ${ }^{33}$. Due to the high demand and multiple uses of poppies in the $15^{\text {th }}-14^{\text {th }}$ Cc. BC, this plant and its derivatives were spread in Egypt so quickly, that they were at some point involved in the sphere of ritual-religious processes ${ }^{34}$. This can explain the depiction of flowers and capsules of the poppies on the walls of a number of palaces and temple complexes of this period, as well as on the wall paintings of the tombs of the pharaohs, the members of their families and high-ranking nobles $^{35}$. Most probably, the same should be said for the poppy-capsuleshaped beads of agate, cornelian, glass, glaze-covered clay and other materials, which appear in the mentioned tombs of the Egyptian elite since the $15^{\text {th }}$ C. BC ${ }^{36}$. Moreover, the special clay molds (Tab. III, fig. 9, 10) uncovered in Tel Amarna testify that the mass production of these glass and glazecovered clay beads had begun ${ }^{37}$. Interestingly, this type of adornments is not found in the contemporaneous archaeological complexes of Cyprus, Palestine, Asia Minor, the Mediterranean and Persia, which points at purely Egyptian origin of these artifacts.

In contrast to these regions, the earlier representations of this plant in the Armenian Highland are observed in the late phase of the Middle Bronze Age Trialeti-Vanadzor culture $\left(20^{\text {th }}-18^{\text {th }} \mathrm{cc}\right)$. They were uncovered in the Lori Berd burials no. 61, 77 and 94 and represent golden hollow objects (pinheads) in the form of poppy capsule and were adjusted to silver pins (Tab.

\footnotetext{
33 Podosyonov 2020: 22 may, https://knife.media/ancient-opiates/

${ }^{34}$ Hepper 1990: 14; Wilkinson 1998: 53; Wilson 2015: 54-57

info@ancientegyptmagazine.co.uk

${ }^{35}$ Saleh, Sourouzian 2007: ill. 79; Rosso 2010: 84-86.

https://www.atthemummiesball.com/poppies-ancient-egypt/

${ }^{36}$ https://www.pinterest.com/pin/323977766948025576/;

https://www.pinterest.es/pin/225186854 4141485/;

https://www.pinterest.es/pin/258957047295045040/; https://www.reddit.com/r

/ArtefactPorn/comments/ab786l/golden_earrings_and_necklace_from_tomb_kv56/;

$37 \mathrm{http}: / /$ www.ancientresource.com/lots/egyptian/amarna_egypt.htmIAmarna
} 
III, fig. 2) ${ }^{38}$. Whether they had only aesthetical significance or were related to other perceptions connected with the poppy-plant, is not clear. However, it is characteristic that the discussed objects were used to pin the cloths or hair, and seem to coincide with the hair decorations of the Poppy Goddess uncovered not far from the Knossos Palace and preserved at the Heraklion Archaeological Museum (Tab. IV, fig. 12) ${ }^{39}$. Concerning the beads in poppycapsule shape, they were spread in the Ararat Valley in the $15^{\text {th }}-13^{\text {th }} \mathrm{cc}$. BC and are known up to now only from the Metsamor burial complexes no. 5, 8, 18, 19 and 20. Judging from the form, materials of which they were made (cornelian, agate), technology, and the period, they were quite similar to the Egyptian samples, and therefore, should be either imported, or imitated here, at least, part of them. In any case, the existence of these objects only in Egypt and in the Ararat Valley, the center of the Armenian Highland, allows to assume direct relations between these two political units and hint that apart from the military cooperation they consisted also of trading, social, elite and other spheres. In this regard, it is not excluded that the appearance of poppyshaped pendants and necklaces in the center of the Armenian Highland is due not only to the willingness of showing high social status through artifacts and dressing up like the powerful ally, but it might be an indication of relation to another important field of activity, to special ritual ceremonies. It should be mentioned that since the mid-II mill. BC the number of kernos-shaped vessels increases significantly in the burials of the rich Late Bronze Age burials of the local elite (Lchashen, Lori Berd, Metsamor, Dilijan, Haghartsin, ljevan,

${ }^{38}$ Devejyan 2006: 25, 47-50, 91, Tabl. III-1, 3, 4, Tabl. IV-6: It should be mentioned, that a similar pin (the only difference is that the pin is made of gold) was accidentally discovered in the central part of the Asia Minor and, according to the publishers, dates back to the time of the New Hittite Kingdom.

https://www.metmuseum.org/art/collection/search/327403

${ }^{39}$ Kritikos, Papadaki 1967: 23; Burkert 1987: 23, 30; Sakellarakis 1987: 91

https://www.hup.harvard.edu/catalog.php?isbn=9780674362819; https://en.wikipedia.org/wiki/ Poppy_goddess; https://en.wikipedia.org/wiki/Poppy_goddess; http://albertis-window.com /2013/10/minoans-the-poppy-goddess-and-opium/ 
Tsaghkalanj, Hrazdan, Verin Naver, Qarashamb etc.) (Tab. IV, fig. 8-10) ${ }^{40}$. These vessels in the ancient Near East and Mediterranean basin were directly related to the cults of the goddesses Demeter and Persephone ${ }^{41}$. The vegetal symbols of the latter were poppies and the mature capsules. Judging by the engraved and/or incised images ${ }^{42}$ on the Near Eastern Middle and Late Bronze Age seals (Ur, Uruk, Akkade, Kish, Tell Asmar, Abu Salabikh, Babylon, Chogha Mish etc.) and clay tablets (Sfiré, Tell Hadidi, Mari, Tell-ed-Dhiba'i, Haradum) (Tab. IV, fig. 1-3, 11-13), the kernos-type vessels and especially their contents were used during special rituals. In the meantime, the participants of the ceremony (tribal leaders, rulers, military leaders, priests, priestesses, etc.) drank or smoked the tincture filled in this vessel (as well as the smoke from the plant mass - pomace and/or hemp), through thin pipes (apparently, reed rods) and falling in hallucinations performed divination. It is possible also that the poppy-decorated necklaces and pendants uncovered both in the Egyptian and Armenian Late Bronze Age burial chambers belonged to these people.

Another interesting aspect linking the early state organizations of the Armenian Highland with the New Kingdom of Egypt is connected to some mutually imported peculiarities of the burial rituals of the mid-II mill. BC.

The matter is that in the burial complexes of the Armenian Highland (Nerkin Getashen, Lchashen, Hacarat, Tolors, Artik, Lori Berd, Metsamor, Shirakavan, Kuchak, Verin Naver, Nor Oshakan Garajamirli, Kyudurlu etc.) of the final phase of the Middle Bronze Age $\left(18^{\text {th }}-16^{\text {th }} \mathrm{cc}\right.$. BC) and the Late Bronze

40 Khanzadyan, Mkrtchyan, Parsamyan 1973: 129; Devejyan 1981: 38-39, Tabl. XI-1, 2; Kushnaryova 1977: 66, image. 79, Tabl. XV-2; Biyagov 1980: 81, Tabl. II-1; Ghafadaryan 1982: 118, Tabl. XII-2; Piliposyan 1982: 13-15; Piliposyan, Gevorgyan, Abgaryan, Zakyan 2015: 42, Tabl. XXIII-2; Kalantaryan, Piliposyan 1996: 78-79; Zakyan, Mamikonyan, Simonyan 2020: 45.

${ }^{41}$ Zhyulen 1961: 123; Barreca 1974: 121; Krasnovskaya 1986: 51; Vinogradova, Kapterev, Starodub 1997: 215-216.

42 Heinrich 1931: tab. 62, 63, 69; Woolley 1934: pl. 194/22, 23; Frankfort 1955: fig. 375; Parrot 1958-1959: 72-75, tab. XXVIII-XXX; Al-Gailani 1965: 36-37, tab. 5/54; Brandes 1979: pl. 30; Buchanan 1981: 124-127, ill. 332-337; Collon 1987, 146, 149, 152, p. III. 627, 640, 660, 668; Kepinski-Lecomte 1992: 367, 414, fig. 149/1-2: Beyer 1996: 21-26, fig. 1-6. 
Age $\left(16 / 15^{\text {th }}-13 / 12^{\text {th }}\right.$ cc. BC) among other artifacts were found perfect bronze objects $^{43}$ which the archaeologists conventionally call "standards". The latter, as objects signifying especially high rank, position and occupation, according to the ritual, together with the other funeral materials, were placed in the burial chamber. These are mostly highly artistic massive objects, of up to 40 $\mathrm{cm}$ height and consist of an anchor-shaped base, tower-shaped trunk, and a zoomorphic or anthropomorphic upper part (Tab. V, fig. 1-5). They could represent the tripartite structure of the world for the local societies of the II mill. BC. The lower, basic part would then represent the netherworld (Chthonos), the tower-shaped core would signify the human world (Chaos), and the upper part - the heaven (Cosmos). In this respect, it can be noticed that the lower part looks like a symbolic boat. The samples with figures of various animals on the upfolding ends of the base spread since the transition period from the Middle to the Late Bronze Age $\left(16^{\text {th }}-15^{\text {th }}\right.$ cc. BC) and are known from Lchashen, Lori Berd, Artik, Metsamor, Kuchak and other contemporaneous $\operatorname{sites}^{44}$. Some samples uncovered in the Lchashen royal burials allow us to discuss their certain role and significance. On the samples found from the burials no 1 and 9, where the composition consists of a pair of horses, a battle chariot, warrior-hunters and a symbolic scene of hunting, there are miniature models of such standards with the mentioned boat-shaped bases (Tab. V, fig 1, 5) ${ }^{45}$. Such images can be seen on the preserved engraved scenes of the clay andiron excavated in the Late Bronze-Early Iron Age layer of Dvin (Tab. V, fig. 6) ${ }^{46}$. It should be mentioned as well that the significant part of these "standards" was uncovered from intact burial

43 Lalayan 1931: 197-199, p. 197; Mnatsakanyan 1957: 146-153; Martirosyan 1964: 110-111, Tabl. X, p. 3, 4; Esayan, Mnatsakanyan 1975: 253-261; Khachatryan 1975: 217-218, p. 129; Arešyan, Simonyan, Sargsyan, Kocharyan, Ohanyan 1979: 216-220; Esayan 1980: 23-29, tab. 27-33, 37-40; Devejyan 1981: 27-32, p. 6, 8; Khanzadian 1995: 51-55, pl. 15; Shanshashvili, Narimanishvili, Narimanishvili 2016: 136-139, tab. LXIX-LXXIII.

${ }^{44}$ Petrossian, Sandrot 1996: 89, ill. 48.

45 Mnatsakanyan 1957: 8; Mnatsakanian 1960: 4-6; Esayan 1966: 139; Esayan, Mnatsakanyan 1975: 260.

46 Kushnaryova 1977: 12. 
chambers placed in situ in the frontal part of the wooden four-wheeled carts or double-wheeled battle chariots, which directly relates them to the royal transportation means ${ }^{47}$. The figurines of water birds and frogs that can sometimes be found on the up-folding ends of the bases indirectly suggest the idea of these lower parts to be symbolic boats.

In this regard, it is interesting to find out why the standards with boatshaped bases appear in the royal burials of the Armenian Highland since the mid-Il mill. BC. The idea of a boat and/or its model as a symbolic transportation measure to the underworld was not typical for the funeral rituals and perceptions before, and, therefore, it should be an imported phenomenon. When discussing the issue in this light, the ties and relations between the New Kingdom of Egypt and the early state organizations of the Armenian Highland since the mid-II mill. BC once again becomes important. As a result of these relations, some rulers of the early state organizations of the Armenian Highland, together with the adoption of a group of elite symbols (scarab-seals, new measurement system, high social ranking by the poppyadornments, group sacrifices of accompanying personnel etc.), adopted also the idea of the boat as a transportation means to the underworld and placed its material representation in the form of the base of standards and placed them in the tomb ${ }^{48}$. From this point of view, by the compositional details and some peculiarities of spiritual perceptions, the mentioned boats are rather similar to the ones depicted on the wall paintings and bas-reliefs of the Middle and mostly of the New Kingdoms of Egypt (Tab. V, fig. 7-10). The boats floating to the netherworld depicted there, are very alike to the boat-shaped base of the Armenian Late Bronze Age standards, the canopy with the pharaoh or with its mummy on the bier in the center are parallel to the

\footnotetext{
${ }^{47}$ Brilyova 2011: 62.

${ }^{48}$ Of course, the idea of going to the netherworld by boat is fixed already in the III mill. BC mythological texts of Mesopotamia, the engravings of some seals, and especially in the epic dedicated to Gilgamesh, but the absence of such representations in the Early Bronze Age societies of the Armenian Highland (according to archaeological materials) allows to link this phenomenon especially to the Egyptian and Mediterranean realities of the Late Bronze Age. On this matter see https://www.ancient.eu/article/221/the-mesopotamian-pantheon/.
} 
quadrilateral tower-shaped trunk $^{49}$, and the $\mathrm{Ba}$ bird $^{50}$ depicted over the canopy (the deity accompanying souls to the netherworld) to the water birds ${ }^{51}$ in the upper part of the Armenian standards. Therefore, it is also possible that in the Middle and New Kingdoms of Egypt and on the territory of the Fertile Crescent (including the Armenian Highland), as a result of cultural relations formed between the ruling elites, the Egyptian funeral ritual endorsed the ceremony of interment on a four-wheeled cart, which until then does not seem to be found in elite funerals. The acceptable example of the abovementioned phenomena can be the kind of a golden funerary barge model belonging to the $17^{\text {th }}$ dynasty pharaoh Kamos (alternate spelling Kamesu, 1554-1549 BC) and uncovered in the sarcophagus of his wife Ahhotep, which is furnished elaborately with four wheels of the Near Eastern funeral cart (Tab. V, fig. 11).

The provided materials allow us to assume that some early state organizations of the Armenian Highland in the $15^{\text {th }}-13^{\text {th }}$ cc. BC (especially in the regions of Shirak, Lori and Ararat Valley) had established connections with the rulers of the New Kingdom of Egypt. Taking into consideration the fact that the territory laying between the North-Syrian steppes in the zone of the Egyptian influence and the central (Ararat Valley) and north (Shirak) parts of the Armenian Highland was vast, and the relations from North Syria to the Armenian Highland could be realized in general through the only available passage: the Pass of Mardin, it can be possible that some early state or tribal organizations (including Alzi, Nairi, Ishuwa, Arme-Shub/pria etc.) of the $15^{\text {th }}$ $13^{\text {th }} \mathrm{cc}$. BC of this zone also participated in these processes ${ }^{52}$. It should be

\footnotetext{
${ }^{49}$ Snisarenko, https://history.wikireading.ru/176338; http://redstory.ru/world/legendy/03.html; It should also be noted that this cultural influence applies not only to the Armenian Highland. An exactly similar structure is typical for the bronze boat models of Mediterranean (mainly Nuraghi) origin dated back to the mid-II mill. BC (Tab. V, fig. 12-14).

50 Zabkar 1968: 73-89.

${ }^{51}$ Avdiev 1948: http://flibusta.site/b/516280/read; Vandersleyen 1971: 138; Höber-Kamel 2003: 23; https://en.wikipedia.org/wiki/Kamose .

52 Of course, it is not excluded that the above-mentioned early state and tribal organizations would have played a decisive role in this case, but the scarcity of written sources, as well as the
} 
mentioned as well that these relations did not determine solely a unilateral vector from Egypt and its allies to the Armenian Highland. Undoubtedly, there was also a path in the opposite direction, and the early state organizations also exported the required assortment to the international market.

Unfortunately, the scarcity of written sources does not yet allow to speak in detail about the size, role and significance of the participation of the inhabitants of the Armenian Highland in these processes. However, there is some data, and their study clearly indicates that in the conditions of militarypolitical, socio-economic, ethno-cultural complex and contradictory processes started since the mid-II mill. BC some of the early state organizations of the Armenian Highland managed to simultaneously realize transactions even with the warring parties. In particular, this aspect is evident from the letter of the Old Hittite king Hattusilis I addressed to Tunia (Tuni-Teshub), the leader of the Hurrian political organization. The latter orders to organize transportation of certain amount of iron (!) from the city of Nihria to the land of the Hittites ${ }^{53}$. Even more eloquent is the data from the cuneiform tablets found at the excavations of the ancient settlement of Tell al-Rimah in Mesopotamia. They directly tell that in contrast to Kanesh (in Asia Minor), the Nihria (Nehria, Neheria) karum of the Armenian Highland not only did not cease to exist in the first half of the II mill. BC, but instead, had become an important transit trading center. It should be mentioned that in these texts the karum is mentioned both as Nih/hria (Ni-ih-ri-a) and as Nairi (Na-i-ri), allowing to presume the identity of these geographical names at the mentioned period ${ }^{54}$. One of the inscriptions (IM-57821) of Tukulti-Ninurta I prove the mentioned aspect, where the discussed toponym appears as "KUR.KUR. Né-hé-e-ri" (Countries of Neheri) in the $12^{\text {th }}$ line, while in the line 28 it is mentioned as "KUR.KUR. Na-i-ri" (Countries of Nairi) ${ }^{55}$. According to the data of the Tell al-

poorly studied local archaeological sites of the Late Bronze Age period, so far forces us to refrain from comments of this nature.

${ }^{53}$ Salvini 1996: 107; Avetisyan 2002: 18-19.

${ }^{54}$ Wiseman 1968: 179, 183, 187, TR-3005, TR-3019.

55 Deller, Fadhil, Ahmad 1994: 459-465. 
Rimah cuneiform inscription, Nihria-Nairi was exporting large amount of tin to North Syria, Northern and Central Mesopotamia. In particular, one of the texts reports on a transaction for 50 minas of tin signed by the merchant Upal-Marduk $^{56}$. It is also possible that other tablets concerning the trade of tin, which do not mention the country, may be related to Nairi ${ }^{57}$. Alongside with this, metal-ware called "nihriyatum" was exported, as well as cereals (both weat and barley), boar fat in special containers and wool of "hudadu" type, which supposedly was processed in special pits ${ }^{58}$. The same tablets testify about another "country" in the south of the Armenian Highland, the land of "Kadmukhi", which exported high quality barley to Mesopotamia. One of Tell al-Rimah tablets (TR-3007) recounts on such a transaction, mentioning also Kubi-Eresh, the son of a certain Shubria, the representative of Kadmukhi ${ }^{59}$. Like a number of large and successful powers of the ancient Near East, the early state organizations of the Armenian Highland, apart from the raw materials and finished goods, sent also people of different professions and labor to the neighboring countries. In particular, Hayasa-Azzi was sending chariot makers and charioteers to the Kingdom of Hattusa, Kummaha was sents soldiers for the security service in the Hittite capital, and Nairi was sending skilled builders from the countries of Kadmuhi and Shubria to Mesopotamia ${ }^{60}$. An interesting evidence is preserved in one of the Middle Assyrian cuneiform tablets. According to the latter, out of 993 foreigners that had taken part in the construction of the city of Kar-Tukulti-Ninurta, 720 were Shubrians, 174 Kadmuhians and 99 Nairians $^{61}$. In the meantime, as each Shubrian had got 6 minas of wool, the majority of Kadmuhians and Nairians

\footnotetext{
${ }^{56}$ Wiseman 1968: TR-3019.

57 Wiseman 1968: TR-3002, 3006, 3011, 3012, 3021, 3030. Saggs 1968: TR-2015, 2030, 2057, 2058, 2081.

${ }^{58}$ Kupper 1982: 17; Gamkrelidze, Ivanov 1989: 23; Wiseman 1968, 179: CAD.H 1956-1968: 222.

${ }^{59}$ Wiseman 1968: 180.

60 Saporetti 1970: 224, 283; HŽP 1971: 199; Freydank 1976: 86-88; Güterbock, van den Hout 1991; Kosyan 2017: 207.

${ }^{61}$ Freydank 1976: 86-87.
} 
had got 20 mina each, and some of them even 1-3 talents of wool. Hence, we can assume that the Shubrians were used as hard labor, while Kadmuhians and Nairians were masons and masters.

In this context, it is possible to make some assumptions about the possible export of raw materials and certain products from the Armenian Highland to the New Kingdom of Egypt, as well as about transactions for the transportation of craftsmen and specialists.

In particular, the Late Bronze Age merchants of the Armenian Highland could be mediators in the export of certain quantities of Lapis Lazuli form the Iranian plateau (the mountains of Badakhshan) to Egypt ${ }^{62}$. It was highly demanded especially during the reign of the pharaohs of the $18^{\text {th }}$ dynasty of Egypt, and the latter, as it was mentioned above, was engaged in cooperation with the leaders of some early state organizations of the Armenian Highland and could get the necessary raw materials through them.

The next important sphere, where Egypt and some early state organizations of the Armenian Highland could cooperate since the mid-II mill. $\mathrm{BC}$ was the industry of weapons, in particular chariot making and issues of its skillful operation. Indeed, already on the wall paintings of the pharaohs of the $18^{\text {th }}$ dynasty, sometimes are depicted images of battle chariots, however, according to prevailing proposal, as a military weapon, they were of unique character, apparently borrowed from Hurrians and, at this stage, they rather symbolized supreme power, than were perceived as military transportation means ${ }^{63}$. Meanwhile, in the period of the New Kingdom, the battle chariots appear in the regular Egyptian army as a separate unit, and as far as the chariot makers and the charioteers from the Armenian Highland (i.e., HayasaAzzi) were especially renowned in the region at that period (see above), it is then not excluded that they took part in retraining and modernization of battle

62 Kulikov 1982: 82, 122, 152; Kesley 2010: 27-28, 34-35, Provided by: Minds@University of Wisconsin; https://core.ac.uk/display/10597540; Zinkina, Ilyin, Andreev, Aleshkovskiy, Koprotaev 2017: 157; Pasturo 2017, https://gemsvalley.ru/lazurit/, https://books. google.ru/books?id=NdEkDwAAQBAJ\&printsec=frontcover $\& \mathrm{hl}=\mathrm{ru} \# \mathrm{v}=$ onepage $\& \mathrm{q} \& \mathrm{f}=\mathrm{false}$ 63 Helck 1978: 337-340. 
chariots of the regular Egyptian army ${ }^{64}$. It is also possible that the experienced craftsmen of the Armenian Highland (in particular, from Subartu-Shubria, Kadmuhi and Nairi) participated in the construction of palaces and temples realized by the pharaohs of the New Kingdom of Egypt and especially during the reign of the $18^{\text {th }}$ dynasty.

So far, concluding this concise discussion about diverse targeted processes established between Egypt and the early state organizations of the southern and central regions of the Armenian Highland (Nairi, Ishuwa, Shubria, Kadmuhi, Etiuni, etc.) in the mid-II mill. BC, we can assume that they had mainly military-political, trading-economic and socio-cultural orientation. Mutually beneficial for each of the parties, they resulted in a long-term $\left(16 / 15^{\text {th }}-12 / 11^{\text {th }}\right.$ Cc. BC) uninterrupted cooperation, although with variable efficiency related to the military-political fluctuations.

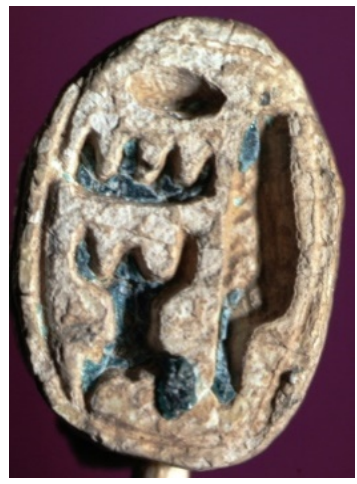

1

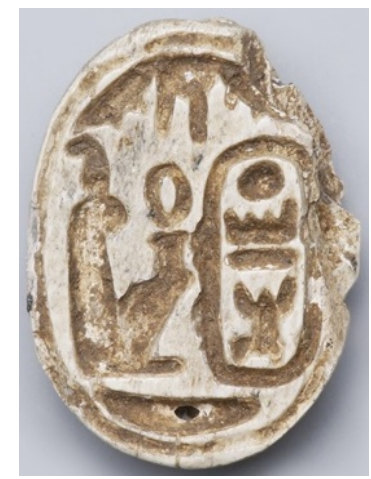

2

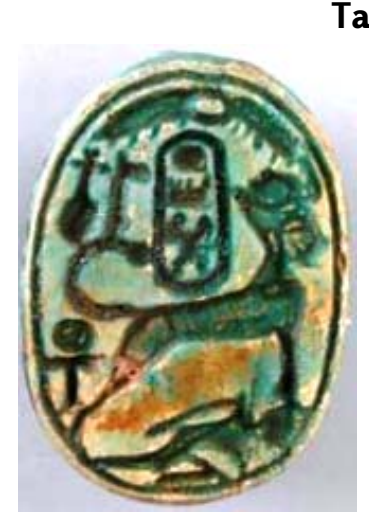

3

${ }^{64}$ It is noteworthy that the king of the Hittites Mursilis II (1320-1290 BC) during one of the campaigns to Hayasa-Azzi, after seizing the fortress of Dukkama (Tukkama), incorporated 3000 captured fighters of the latter into his army (Godawa-Chrzanowska 2020: 376). To this we should add the fact that battle chariots either complete or partial and/or their remarkable bronze models were uncovered during the excavations of the Late Bronze Age burials of the ancient cemeteries of Lchashen, Lori Berd and Keti (Voskehask). In any case, at the first sight the Egyptian battle chariots are closer to the Armenian samples rather than the ones from the Asia Minor. 


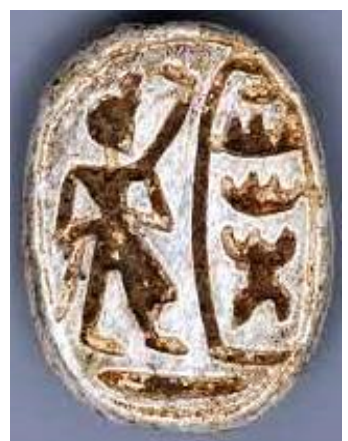

4

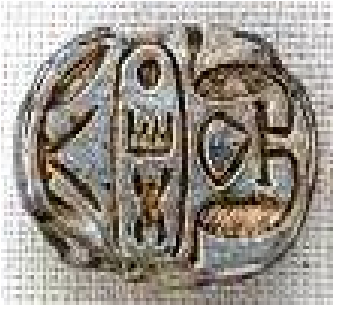

6

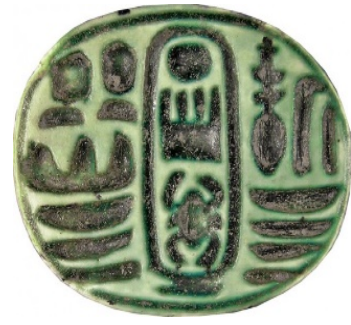

7

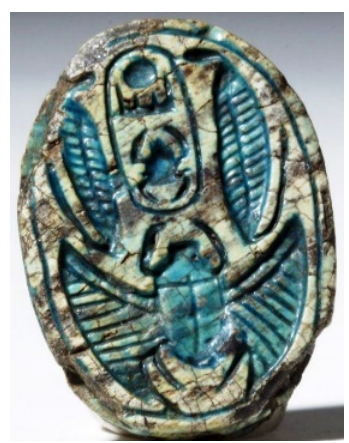

5

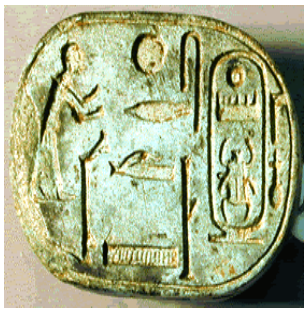

8

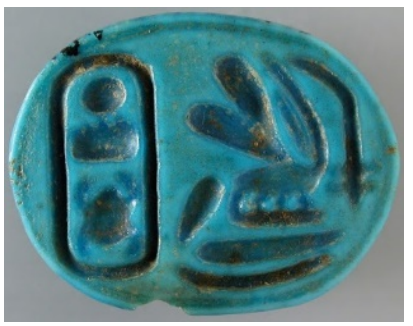

9

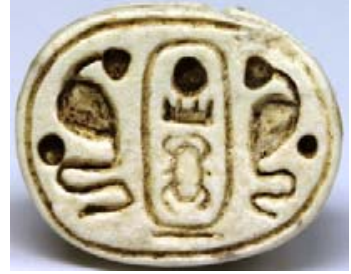

11

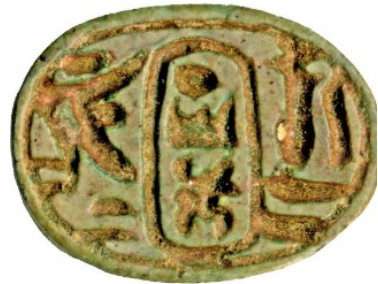

12

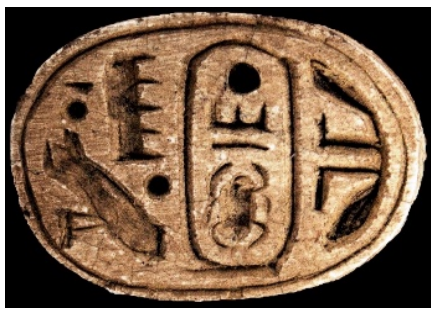

10

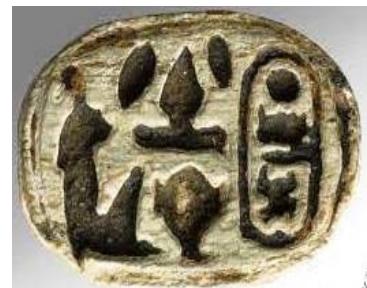

13 


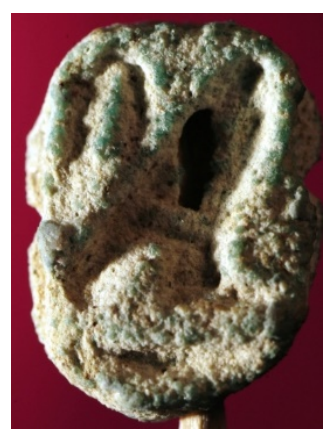

14

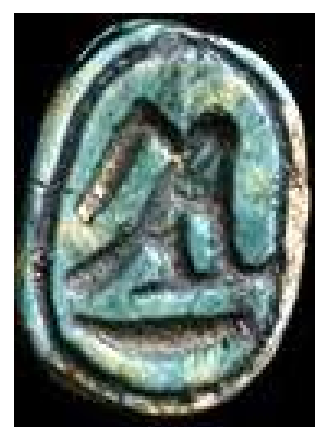

15

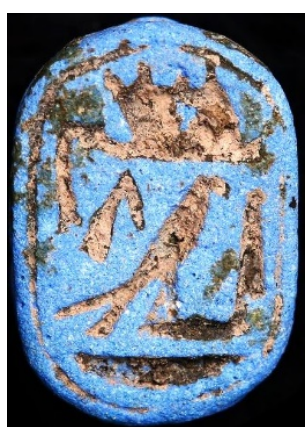

16

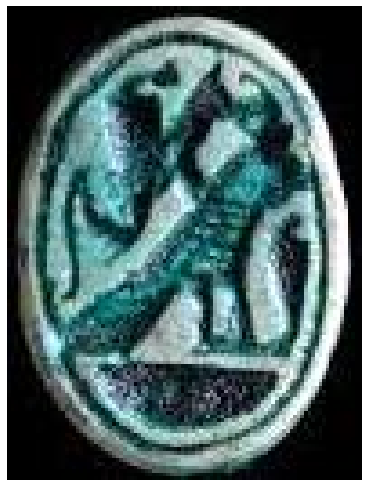

17

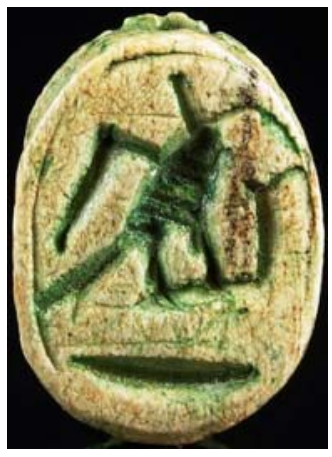

18

Table II

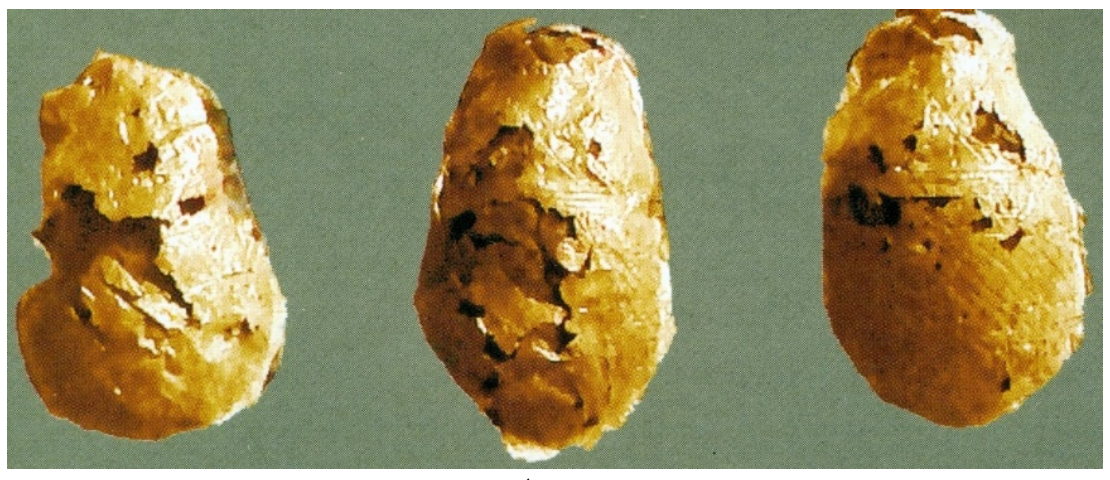

1 


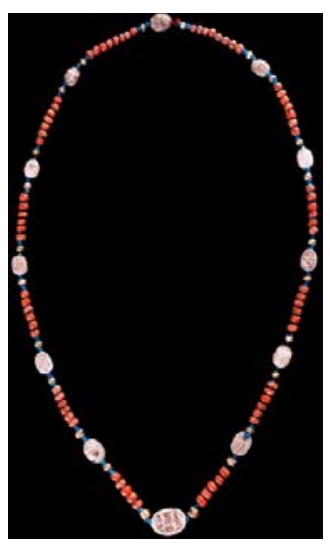

2

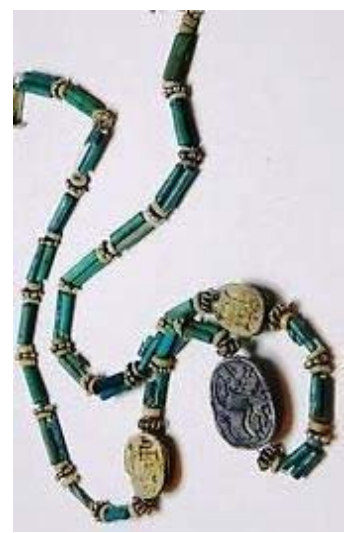

5

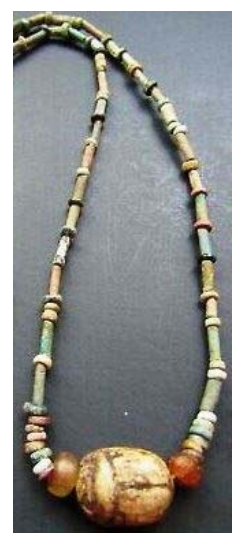

3

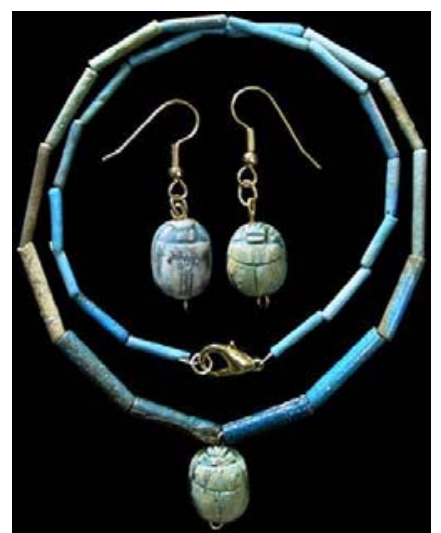

6

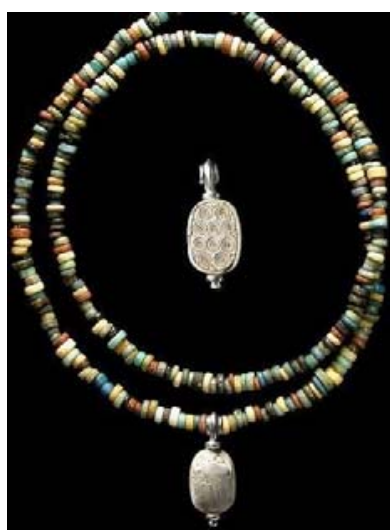

4

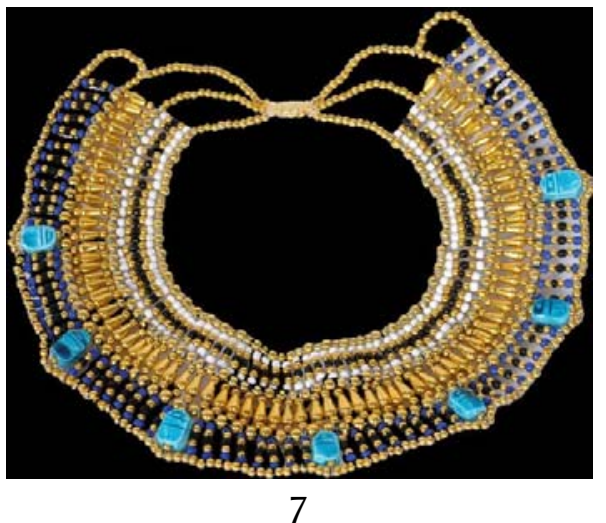

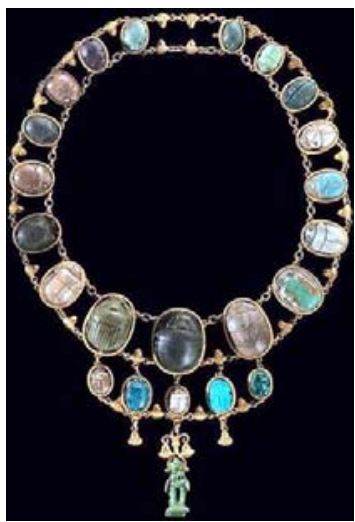

8 
Table III

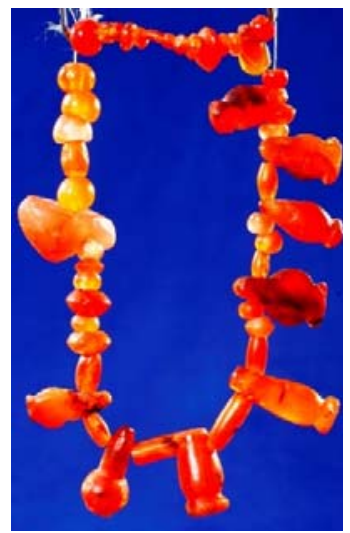

1

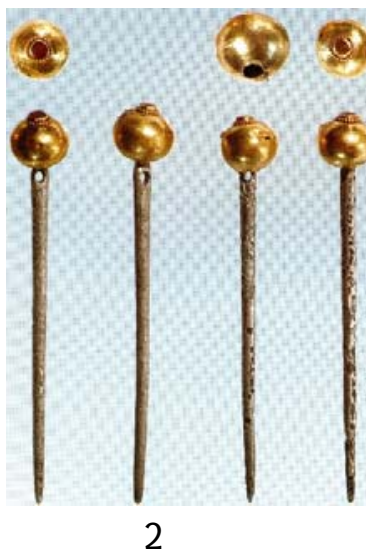

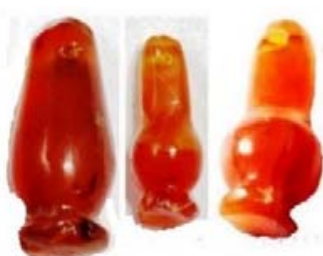

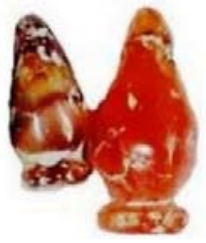

3

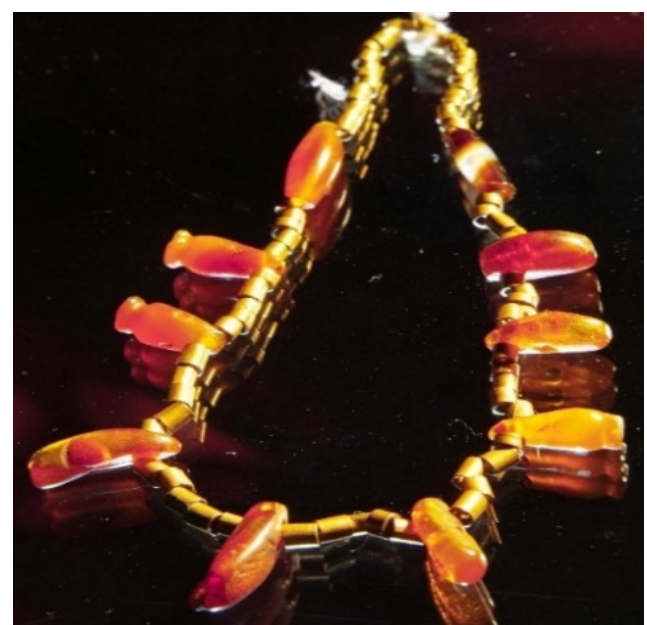

4

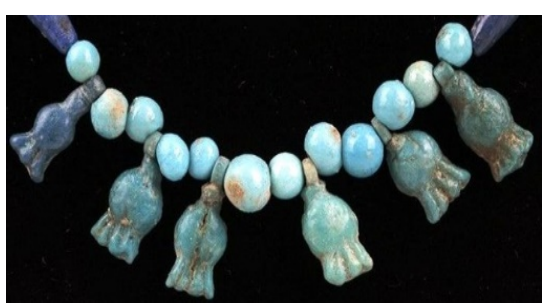

5

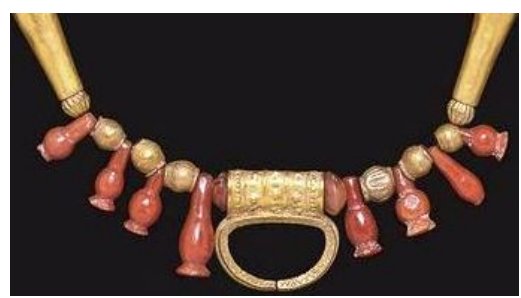

6 


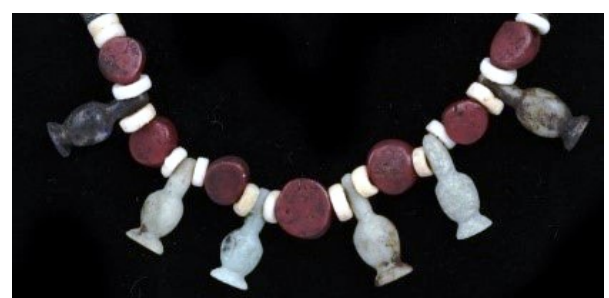

7

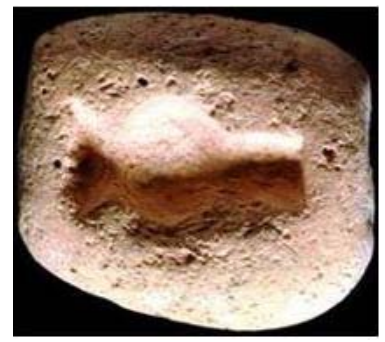

9

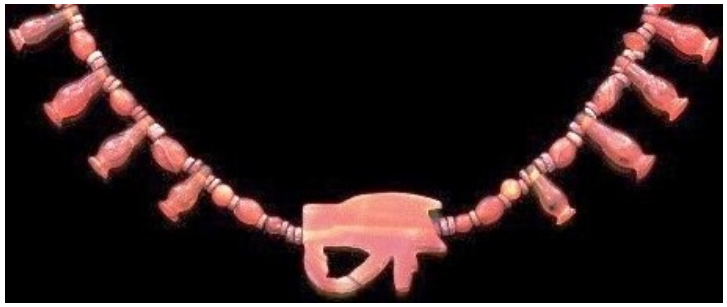

11

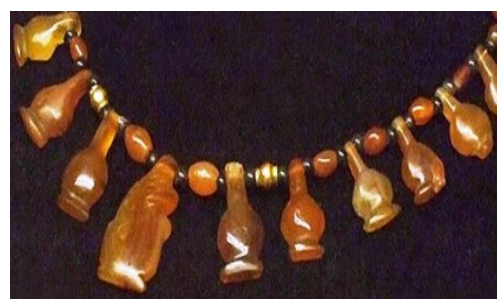

8

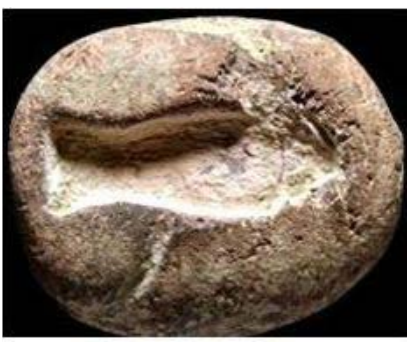

10

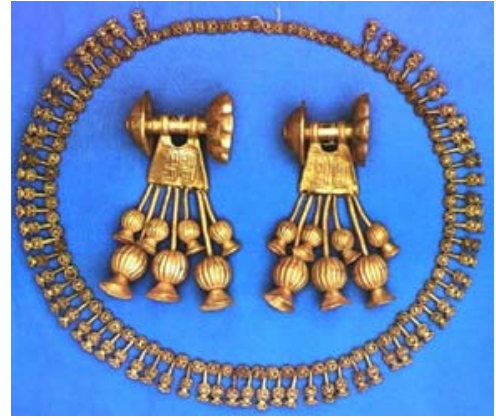

12

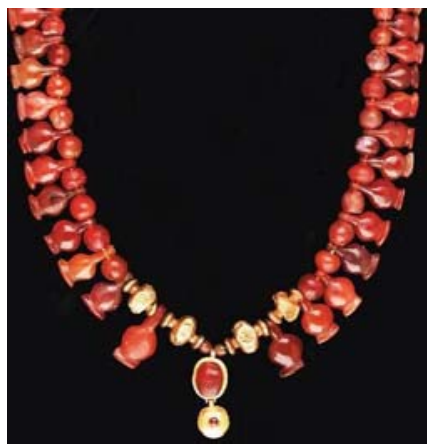

14 
Table IV

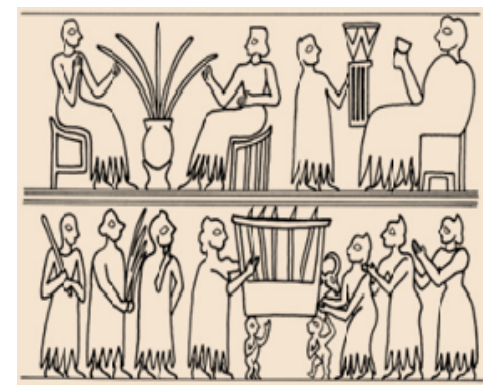

1

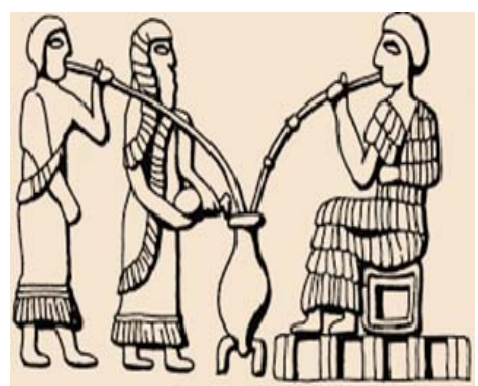

2

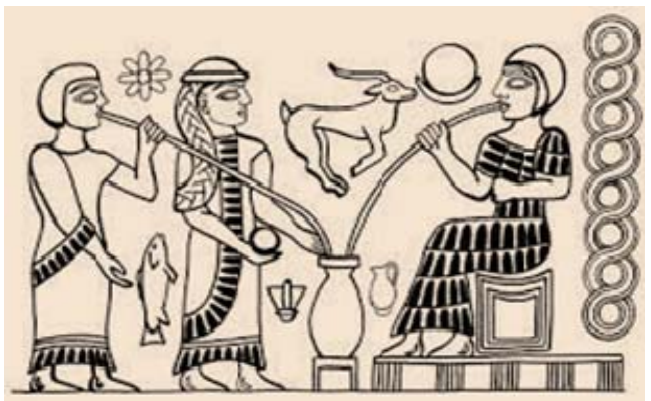

3
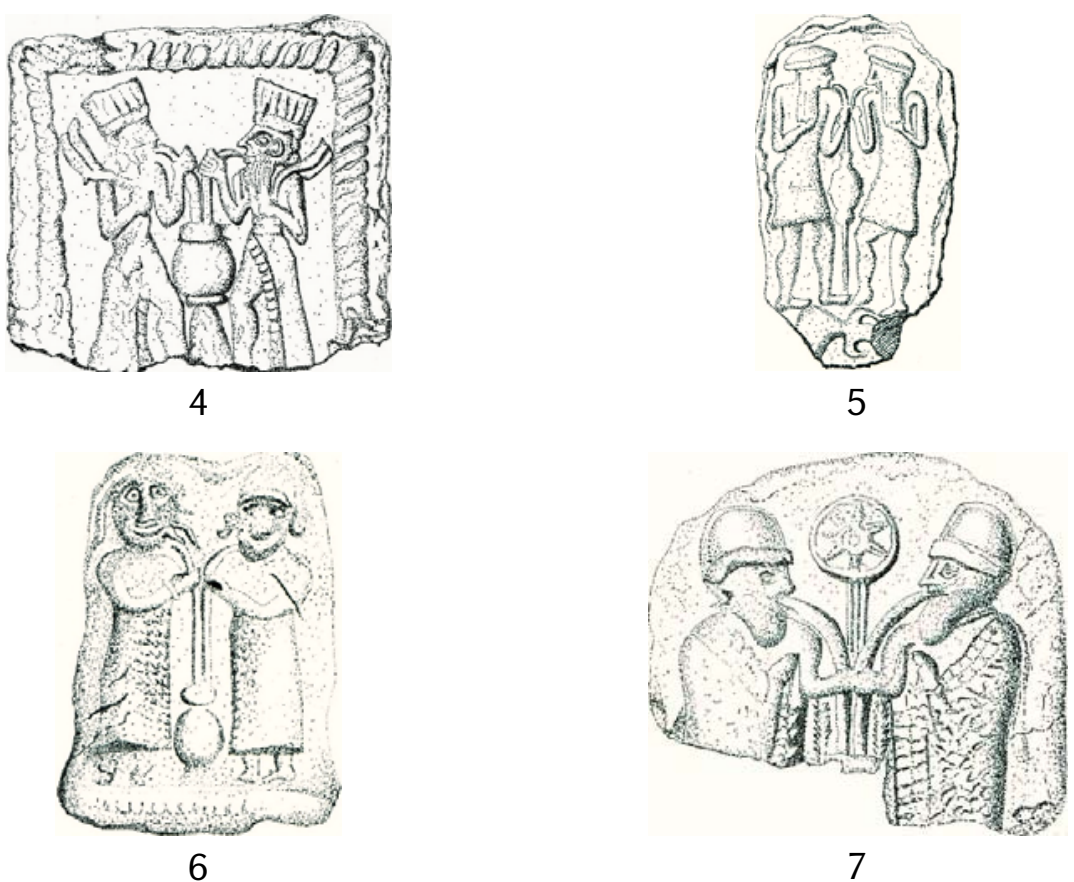


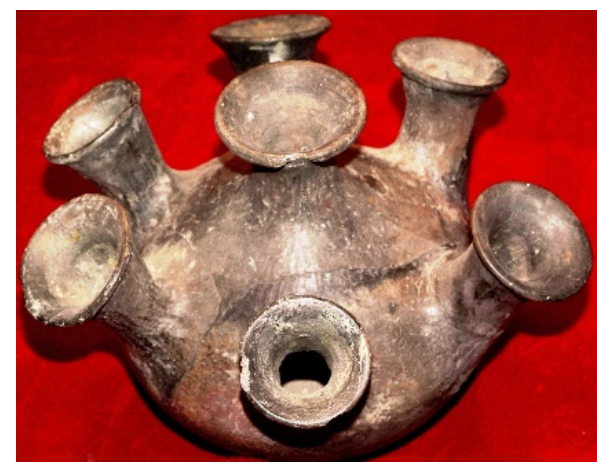

8

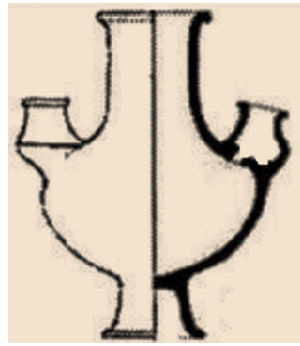

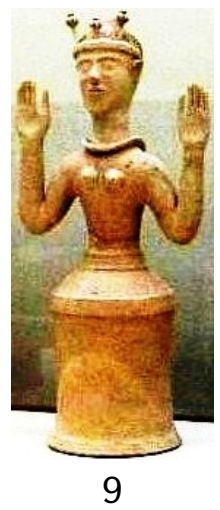

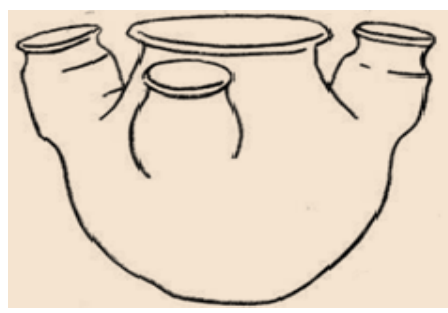

10

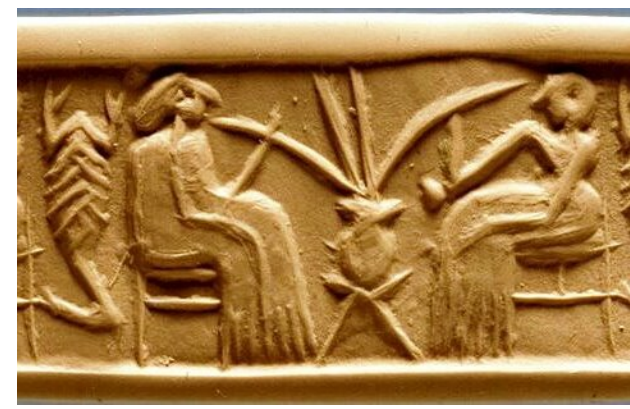

11

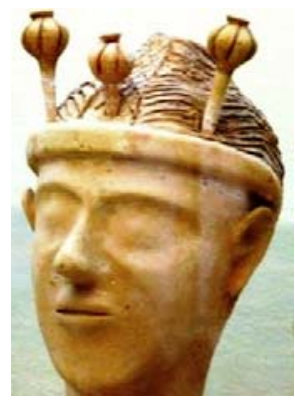

12

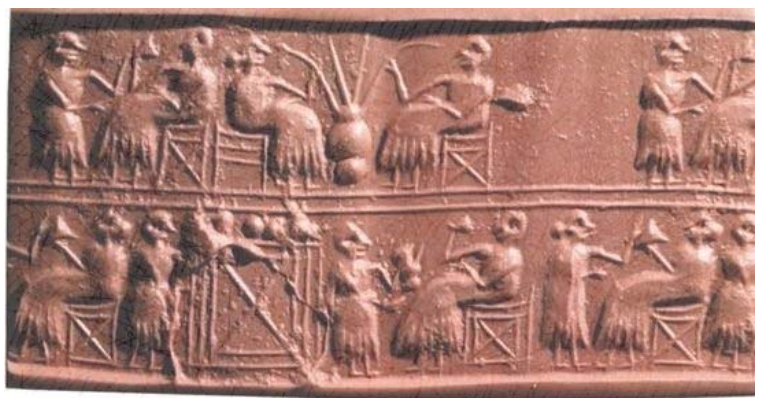



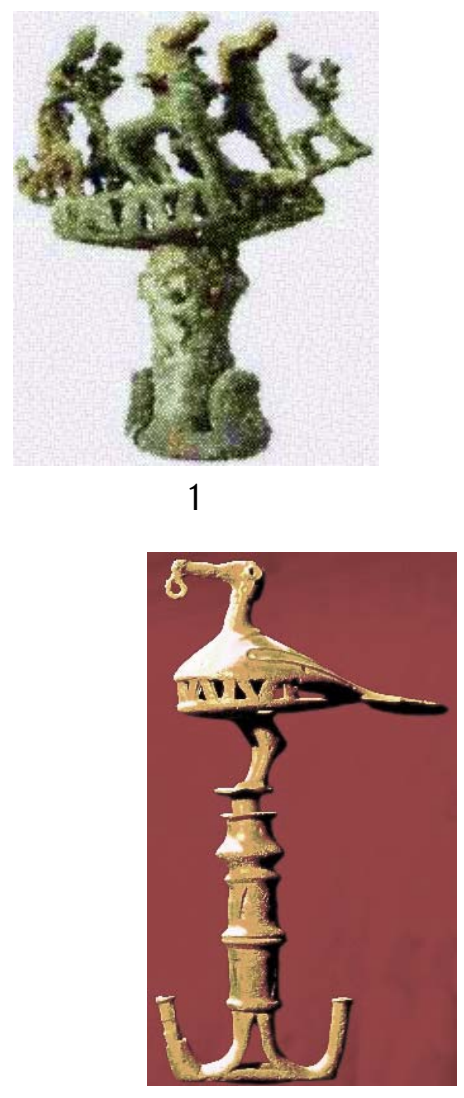

4

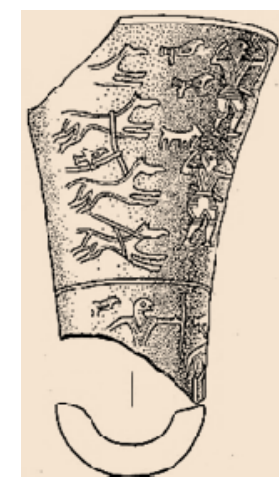

6
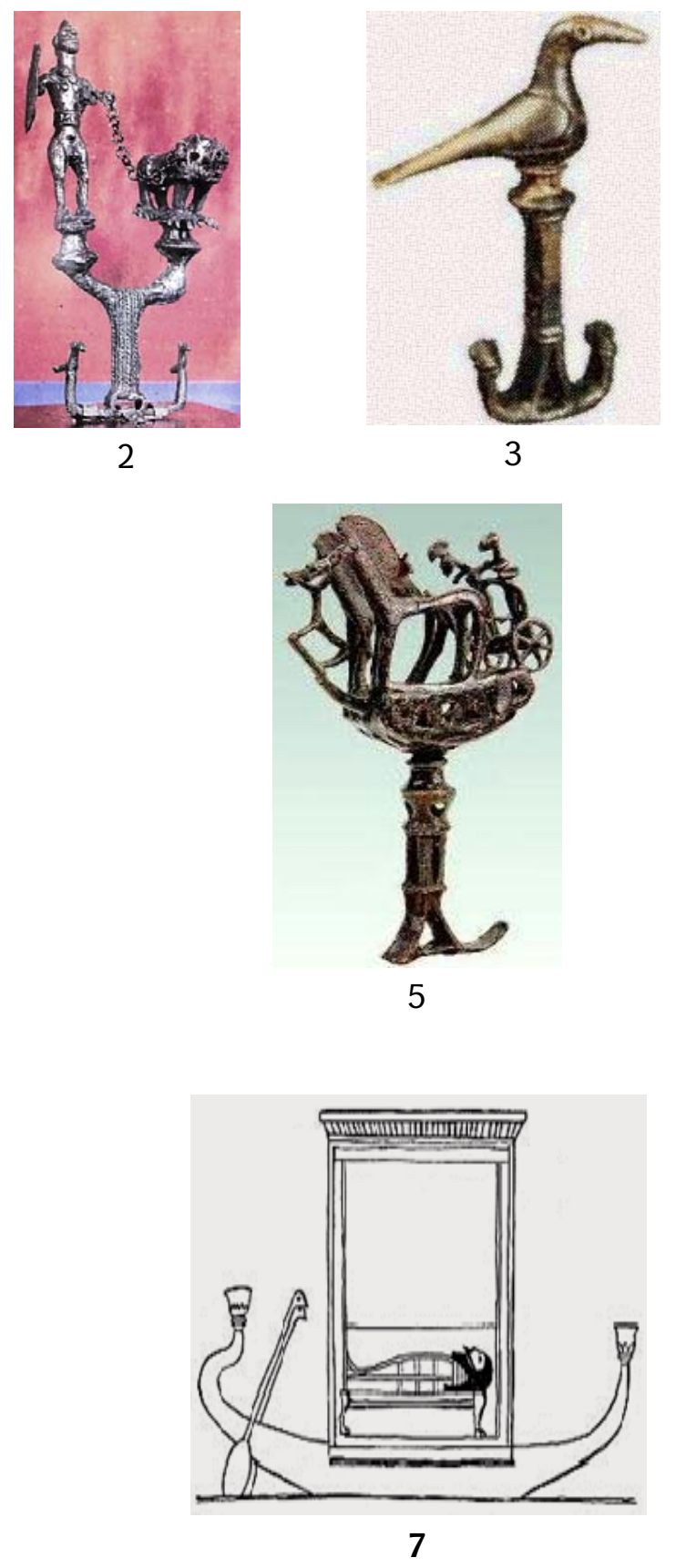


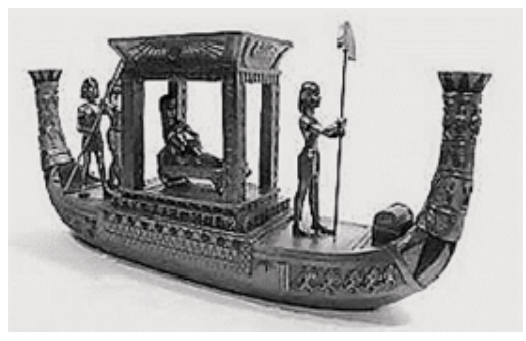

8
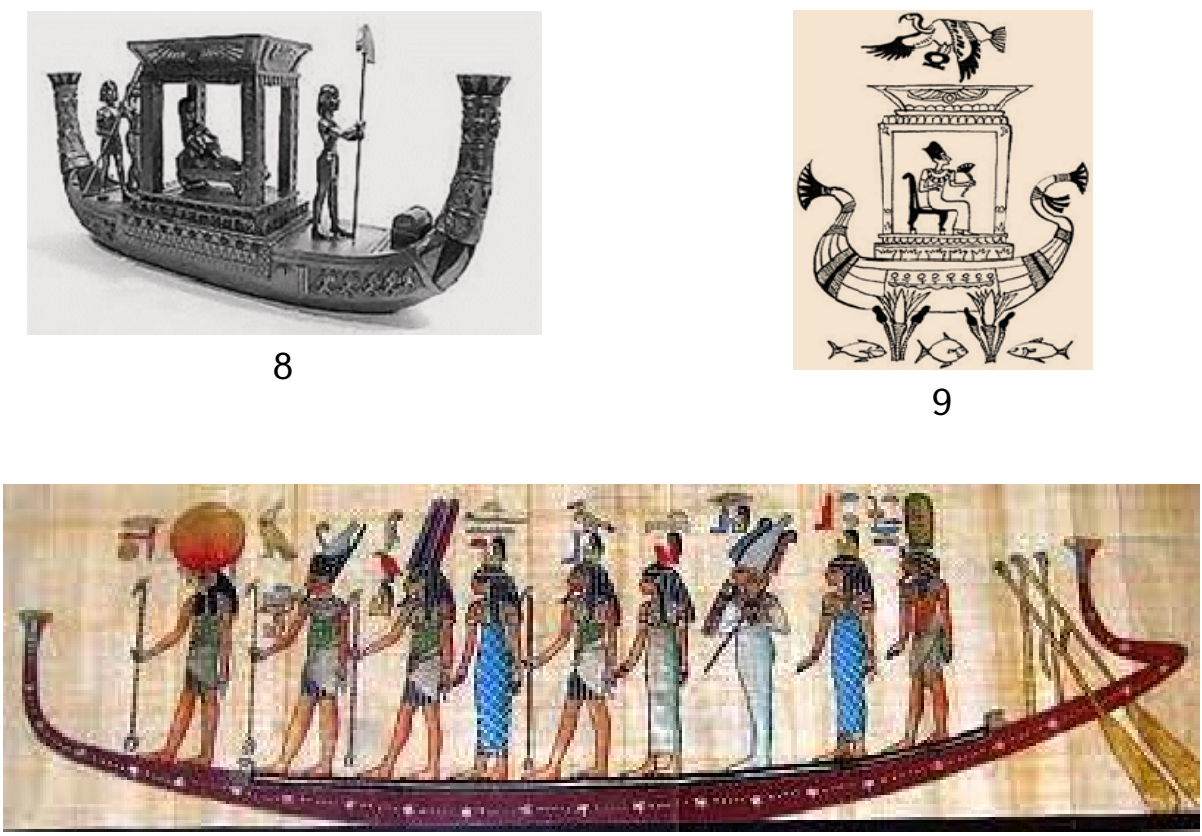

10

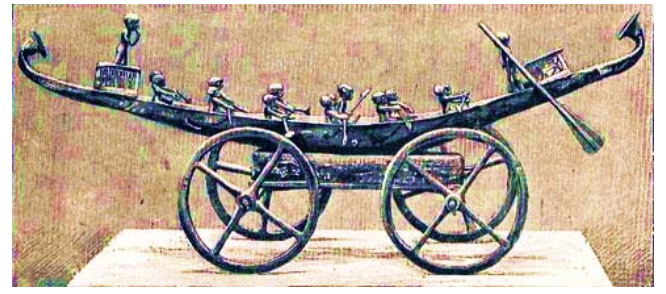

11

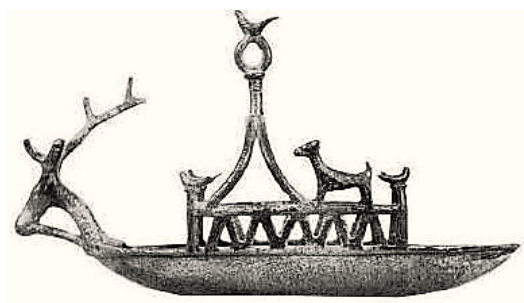

13

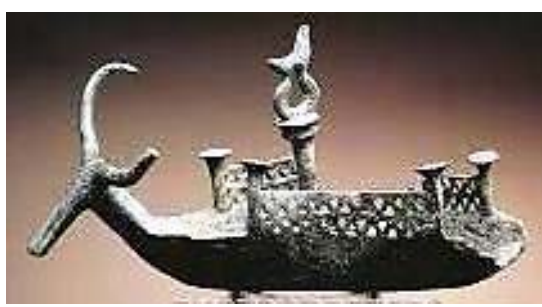

12

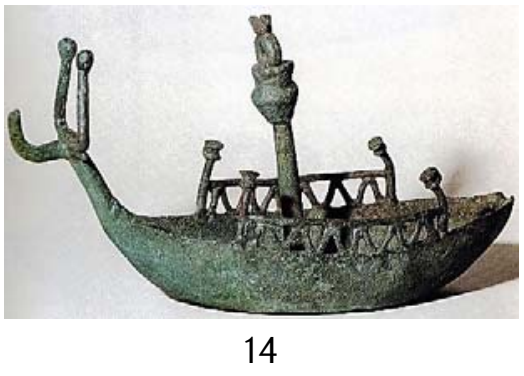




\section{BIBLIOGRAPHY}

Ajango K. M. 2010: New Thoughts on the Trade of Lapis Lazuli in the Ancient Near East c. 3000-2000 B.C, Minds@University of Wisconsin; https://core.ac.uk/display/10597540.

Al'dred S. 2004: Yegiptyane: Velikiye stroiteli pyramid (Egyptians: Great builders of pyramids), Moscow (In Russian).

Allen J. P. 2000: Middle Egyptian: An Introduction to the Language and Culture of Hieroglyphs, Cambridge, Cambridge University Press.

Al-Galiani L. 1965: Tell edh-Dhiba' I, Sumer, vol. 21, Paris.

Anslinger H. J., Tompkins W. F. 1953: The Traffic in Narcotics, New York.

Arešyan G., Simonyan H., K'očaryan G., Ohanyan H. 1979: Hayagitakan kentroni 1977-78 $t^{\prime} t$ '. daštayin hnagitakan aškhatank'nerə (Fieldwork of the Center for Armenian Studies in 1977-78), Banber Yerevani hamalsarani, № 2, 216-220 (In Armenian).

Arnott R.G. 1999: Opium, in: Minoan and Mycenaean Tastes. Athens.

Avdiyev I. V. 1948: Voyennaya istoriya Drevnego Yegipta , t. I, Vozniknoveniye i razvitiye zavoyevatel'noy politiki do epokhi krupnykh voyn XVI-XV vv. do kh.e., (Military history of Ancient Egypt, vol. I, The emergence and development of the policy of conquest before the era of major wars of the XVI-XV cc. BC, Moscow, Publishing House "Sovetskaya nauka"), (In Russian). http://flibusta.site/b/516280/read .

Avetisyan H. 2002: Haykakan leŕnaškharhi ev Hyusisayin Mijagetk'i petakan kazmavorumneri k'ağak'akan patmut'yunə m.t'.a. XVII-IX darerum (Avetisyan H., The political history of the state formations of the Armenian highland and Northern Mesopotamia (XVII - IX cc. B.C.), Yerevan (In Armenian).

Avetisyan Gr. M. 1984: Gosudarstvo Mitanni (Voyenno-politicheskaya istoriya v 18-17 vv. do n.e.), Yerevan (In Russian).

Barreca F. 1974: La Sardegna Fenicia e Punica, Sassari.

Bertman S. 2007: Mesopotamiya (Entsiklopedicheskiy slovar') (Mesopotamia (Encyclopedic Dictionary)), Moskva (In Russian).

Beyer D. 1996: A propos d'une terre cuite de Sfiré, in Gasche H., Hrouda B. (eds), Collectanea Orientalia: histoire, arts de l'espace et industrie de la terre. Études offertes en hommage à A. Spycket, Neuchâtel, 21-26.

Bisset N. G., Bruhn J. G., Curto S., Holmstedt B., Nyman U., Zenk M. H. 1994: Was opium known in $18^{\text {th }}$ dynasty ancient Egypt? An examination of materials from 
the tomb of the chief royal architect Kha, Journal of Ethnopharmacology, vol. 41, Issues 1-2, 99-114.

Bisset N. G., Bruhn J. G., Curto S., Holmstedt B., Nyman U., Zenk M. H. 1996: Was opium known in $18^{\text {th }}$ dynasty ancient Egypt? An examination of materials from the tomb of the chief royal architect Kha. In: Ägypten und Levante, № 6, 199-201.

Biyagov L. 1980: Arkheologicheskiye materialy iz Lusabatsa, Archaeological materials from Lusabats, Bulletin of Social Sciences of the Academy of Sciences of the Arm SSR, № 2, Yerevan, 77-82 (In Russian).

Bonewitz R. L. 2003: lyeroglify dlya načinayuščikh (Hieroglyphics), Moskva (In Russian).

Boonstra S. 2019: Scarab and Seal Amulet Production in the Early Eighteenth Dynasty: An Analysis of the Materials, Technology, and Surface Characteristics to Determine Seal Amulet Workshops (A thesis submitted to the University of Birmingham for the degree of $\mathrm{PhD}), 154-156$. https://etheses.bham.ac.uk/id/eprint/9730/1/Boonstra2019PhD.pdf

Brandes M. 1979: Siegelabrollungen aus den Archaischen Bauschichten in UrukWarka, Freiburger Altorientalische Studien, № 3, Wiesbaden.

Brileva O. A. 2011: Illyustratsiya odnogo mifa na primere izobraženiy voina i I'va na štandartakh XVI-XIV vv. do n.e., in: Antiquity: Historical Significance and Specificity of the Source, Proceedings of the International Scientific Conference dedicated to the memory of Edwin Arvidovich Grantovsky and Dmitry Sergeevich Raevsky, vol. V, Moscow, 60-63.

Buchanan B. 1981: Early Near Eastern Seals in the Yale Babylonian Collections, New Haven and London.

Budge E.A. Wallis 2000: Putešestviye duši v tsarstve mertvykh (Yegipetskaya kniga Mertvykh) (Journey Soul in Kingdom Dead), Moskva (In Russian).

Burkert W. 1987: Greek religion, Cambrigde, Harvard University Press.

Chernykh Y. 1989: Metall i drevniye kul'tury: uzlovyye problemy issledovaniya ( $\mathrm{v}$ kn. "Yestestvennonauchnyye metody v arkheologii»), Moskva (In Russian).

Collon D. 1987: First Impressions. Cylinder Seals in the Ancient Near East, London.

Deller K., Fadhil A., Ahmad K. 1994: Two New Royal Inscriptions Dealing with Construction Work in Kar-Tukulti-Ninurta, Baghdader Mitteilungen, B. 25, Berlin, 461-467.

Devejyan S. G. 1981: Lori Berd I (Rezul'taty raskopok 1969-1973 gg.) (Results of excavations 1969-1973), Yerevan (In Russian). 
Devejyan S.G. 2006: Lori berd II (mijin bronz) (Middle Bronze), Yerevan (In Armenian).

D'yakonov I.M. 1968: Predystoriya armyanskogo naroda. Istoriya Armyanskogo nagor'ya s 1500 po 500 g. do n. e. Khurrity, luviytsy, proto'armiane (Prehistory of Armenians. The History of Armenian Highland from 1500 to 500 BC. Hurrites, Luwians, Protoarmenians), Yerevan (In Russian).

Frankfort H. 1955: Stratified Cylinder Seals from the Diyala Region, Chicago (Oriental Institute Publications, vol. LXXII).

Freydank G. 1976: Noviye danniye ob otnošeniyakh Sredneassiriyskogo tsarstva s severnymi i severo-zapadnymi stranami (Freydank H., New Data on the Relations Between the Middle Assyrian Kingdom and the North-Western Regions)), Drevniy Vostok, №. II, Yerevan, 86-88 (In Russian).

Gabra S. 1956: Papaver species and opium through the ages, Bulletin de I'Institut d'Egypte, vol. 37, № 1, 37-54.

Ğafadaryan K. 1982: Dvin k'ağak'ə ev nra peğumnerə, h. II, Yerevan (Dvin city and its excavations) (In Armenian).

Gamkrelidze, T. V., Ivanov V. V. 1989: Perviye indoyevropeytsy v istorii: Predki tokhar v drevney Peredney Azii,Vestnik Drevney Istoriy, No. 1, 14-39 (The first Indo-europeans in History: Ancestors of Tokharians in Ancient Near East) (In Russian).

Gurney O. R. 1987: Khetty (poslesloviye V.G. Ardzinba) (The Hittites), Moskva (In Russian).

Godawa-Chrzanowska A. 2020: Nachbarn des Oberen Landes, Politische Geographie der Grenzregionen des Reiches $H_{\lrcorner}$atti. Inauguraldissertation zur Erlangung des Akademischen Grades eines Dr. Phil., vorgelegt dem Fachbereich 07 Geschichts- und Kulturwissenschaften der Johannes Gutenberg-Universita " $t$ Mainz.

Gol'tsman Ye. 2000: Entsiklopediya magičeskikh kamney i rasteniy, Moskva, 327-328 (Enciclopedia of Magic stones and plants) (In Russian).

Grayson A. K. 1975: Assyrian and Babylonian Chronicles, New York

Grinkevich N. I., Sorokina A. A. 1988: Legendy i byl' o lekarstvennykh rasteniyakh, Moskva (Legends and true stories about medicinal plants) (In Russian).

Guiterbock H. G., Th. P. J. van den Hout 1991: The Hittite Instruction for the Royal Bodyguard, Chicago (Assyriological Studies, № 24). 
Hassaan G. A. 2017: Mechanical Engineering in Ancient Egypt, Part 58: Semiprecious Stones Applications, in International Journal of Emerging Engineering Research and Technology (IJEERT), vol 5, Issue 9, Coastal Highway, Lewes, 21, fig 5. 20-31.

Heinrich E. 1931: Fara: Ergebnisse der Ausgrabungen der Deutschen Orient Gesellschaft in Fara und Abu Hatab 1902/03, Berlin.

Hepper F. N. 1990: Pharaoh's Flowers: The Botanical Treasures of Tutankhamun, London: H.M.S.O. London.

Helck W. 1978: Ein indirekter Beleg für die Benutzung des liechten Streitwagens in Ägypten zu ende der 13 Dynastie, JNES, vol. 37, № 4, 337-340.

Helck H. E. O. 1999: Kleines Lexikon der Ägyptologie. 4 überarbeitete Auflage, Wiesbaden.

Höber-Kamel G. 2003: Von den Hyksos zum Neuen Reich. In: Kemet, Heft 2. Berlin.https://ru.wikipedia.org/wiki/\%D0\%9A\%D0\%B0\%D0\%BC\%D0\%BE\%D1\%81:

Julyan M., Dircksen M. 2011: The Ancient Drug Opium, Akroterion, № 56, 75-90.

K'alant'aryan A., P'iliposyan A. 1996: Dvini kernosadzev anot'nerə ev nrants hinarevelyan zugaherinerə, "HH-um 1993-1995 t't'. hnagitakan hetazotut'yunneri ardyunk'nerin nvirvac'X gitakan nstašrjan», Yerevan, 78-79 (In Armenian).

Kapantsyan G.A. 1947: Khayasa - kolybel' armyan. Etnogenez armyan i ikh nachal'naya istoriya, Yerevan (In Russian).

Kepinski-Lecomte Ch. 1992: Haradum I. Une ville nouvelle sur le Moyen-Euphrate (XVIIle-XVIle siécles av.J.-C), Paris: Éditions Recherche sur la Civilisations, ADPF.

Khačatryan T. 1975: Drevnyaya kul'tura Širaka, Yerevan (The Ancient culture of Shirak) (In Russian).

Khačatryan V. 1971: Vostočnyye provintsii Khettskoy imperii (Voprosy toponimiki), Yerevan (Eastern provinces of the Hittite Empire (Toponymic issues)) (In Russian).

Khanzadyan E. V., Mkrtčyan K. H., Parsamyan E. S. 1973: Mec'amor (Usumnasirut'yun 1965-1966 $\mathrm{t}^{\prime} \mathrm{t}$ '. peğumneri tvyalnerov), Yerevan (In Armenian).

Khanzadyan E. 1982: Razvitiye paleometalličeskikh kul'tur Armyanskogo Nagorye (Development of paleo-metallic cultures of the Armenian Highland), - Yerevan, 3337, (In Russian).

Khanzadian E. 1995: Metsamor 2, La Necropole (Les Tombes du Bronze Moyen et Resent), vol. 1, CPO HS I, Neuchâtel - Paris.

Khanzadyan E., Sarkisyan G. Kh., D'yakonov I. M. 1983: Vavilonskaya girya XVI v. do n.e. s klinopisnoy nadpis'yu iz raskopok Metsamora (1. Obstoyatel'sva nakhodki giri, 2. Klinopisnaya nadpis' na gire), Drevniy Vostok, № IV, Yerevan, 113-122 (Babylonian weight of the 16th century BC. with a cuneiform inscription from the 
excavations of Metsamor (1. The circumstances of the finding of the weight, 2. The cuneiform inscription on the weight)) (In Russian).

Khanzadian E. V., Sarkisian G. Kh., Diakonoff I. M. 1992: A Babylonian Weight from the Sixteenth Century B.C. with Cuneiform Inscription from the Metsamor Excavations, Soviet Anthropology and Archaeology, vol. 30, № 4, 75-83.

Khojaš S. I. 1976: Tsarskiye skarabei, skarabeoidy i pechati epokhi novogo tsarstva iz GMII im. A.S. Pushkina i Ermitaža, Vestnik Drevney Istorii, № 2, 85-113 (Royal Scarabs, Scarabaeoids and Seals of the New Kingdom Era from SMH after A. Pushkin, and Hermitage) (In Russian).

Khojaš S. I. 1999: Drevneyegipetskiye skarabei (Katalog pečatey i skarabeyev iz muzeyev Rossii, Ukrainy, Kavkaza i Pribaltiki), Moskva (Ancient Egyptian scarabs (Catalog of seals and scarabs from the museums in Russia, Ukraine, the Caucasus and the Baltic States)) (In Russian).

Korostovtsev M. A. 1978: Povest' Peteise III. Drevneyegipetskaya proza (Perevod s drevneyegipetskogo, vstupitel'naya stat'ya i kommentarii M. A. Korostovtseva), Moskva (The Story of Peteis III. Ancient Egyptian prose) (In Russian).

Kosyan A. 1997: Khet'akan terut'yunə ev Akhkhiyavan (Troyakan paterazm), (The Hittite Empire and Ahhiyawa (The Trojan War), Yerevan (In Armenian).

Kosyan A. 1998: Tun T'orgomay (The "House of Torgom" (Myth and reality), Yerevan (In Armenian).

Kosyan A. 1999: Merdzvorarevelyan č‘gnažamə ev Haykakan leṙnaškharhə (The XII Century B.C. Near Eastern Crisis and the Armenian Highland), Yerevan (In Armenian).

Kosyan A. 2004: Haykakan lernnaškharhi teğanunnerə (əst khet‘akan sepagir ağbyurneri) (The Toponyms of the Armenian Highland (According to the Hittite Cuneiform Sources), Yerevan (In Armenian).

Kosyan A. 2017: Integratsion gorc'ənt'atsnerə ep'ratyan kontaktayin gotum m.t'.a. II-I hazaramyaknerum, (Integrational Processes in the Euphratian Contacting Zone in the II-I Millennium B. C., Oriental Studiesin Armenia, Vol. 3) Arevelagitut'yunə Hayastanum, № 3, Hin ev Mijnadaryan Hayastanə ev ir harevannerə, Yerevan, 200-212 (In Armenian).

Kramer S. N. 1954: First Pharmacopoeia in Man's Recorded History, in American Journal of Pharmacy, № 126, 76-84.

Krasnovskaya N. A. 1986: Proiskhoždeniye i etničeskaya istoriya sardintsev (Origin and ethnic history of the Sardinians), Moskva (In Russian). 
Kritikos P. G., Papadaki S. P. 1967: The History of the Poppy and of Opium and Their Expansion in Antiquity in the Eastern Mediterranean Area, in: Bulletin of Narcotics, vol. 19, issue 3, 17-38.

Kulikov B. F. 1982: Slovar' kamney-samotsvetov (The Gemstone Dictionary), Leningrad (In Russian).

Kupper J.-R. 1982: Mari: Entre la Mesopotamie et la Syrie du Nord a L'Epoque Paleobabylonienne, Thracians and Mycenaeans (Ed. by J. G. P. Best and N. M. W. de Vries), Leiden - Sofia.

Kušnaryova K. Kh. 1977: Drevneyshiye pamyatniki Dvina, Yerevan (Ancient monuments of Dvin) (In Russian).

Kuziščin V.I. 2005: Velikaya Yegipetskaya deržava v epokhu Novogo tsarstva (XVI-XII vv. do n.e.) (The Great Egyptian Empire in the era of the New Kingdom (XVI-XII centuries BC)), Moskva (In Russian).

Lalayan Ye. 1931: Dambaranneri peğumner Khorhrdayin Hayastanum (The grave excavations in Soviet Armenia), Yerevan (In Armenian).

Lurker M. 1998: Yegipetskiy simvolizm (iz Serii "Simvoly", kniga IX) (Egyptian Symbolism (from the series "Symbols", Book IX),), Moskva (In Russian).

Macqueen J. G. 1983: Khetty i ikh sovremenniki v Maloy Azii (Hittites and their contemporaries in Asia Minor), Moskva (In Russian).

Manniche L. 1999: An Ancient Egyptian Herbal, London, British Museum Press.

Martirosyan A. 1964: Armeniya v epokhu bronzy i rannego železa (Armenia in the Bronze Age and Early Iron Age), Yerevan (In Russian).

Martirosyan H. 1971: Hayastanə zargatsac' kam uš bronzi žamanakašrjanum (Armenia in the developed or Late Bronze Age), HŽP, h. 1, 203-229, Yerevan (In Armenian).

Merelin M. D. 2003: Archaeological Evidence for the Tradition of Psychoactive Plant Use in the Old World, Economic Botany, vol. 57, issue 3, 295-323.

Merrillees R. S. 1962: Opium trade in the Bronze Age Levant, Antiquity, № 36, 287292.

Mkrtčyan R., P'iliposyan A. 2011: Sotsial-k'ağak'akan gorc'ənt'atsnerə Haykakan leṙnaškharhum m.t'.a. II-I hazaramyaknerum, «K'ağak'akan hartser - 2011 (Pahpanoğakan hosanqə ev Hayastani Hanrapetut'yan k'ağak'akan gorc'ənt'atsnerə)», mijbuhakan gitažoğovi nyut'er (Socio-political processes in the Armenian Highlands II-I millennia, "Political Issues - 2011 (The Conservative Current and Political Processes of the Republic of Armenia)", Interuniversity Conference), Yerevan, 250-263 (In Armenian). 
Mkrtčyan R. 2001: Paleoantropologiya Oromskogo mogil'nika, "Materialy po antropologii Armenii" (Paleoanthropology of the Horom's burial ground, "Materials on the anthropology of Armenia"), I, Yerevan (In Russian).

Mnatsakanyan A. O. 1957: Raskopki kurganov na poberež'ye oz. Sevan v 1956 g. (predvaritel'noye soobshcheniye) (Excavation of burial mounds on the shores of Lake Sevan in 1956 (preliminary report)), SA, No. 2, 146-153, (In Russian).

Mnatsakanian A. O. 1960: Bronze Age Culture on Lake Sevan Coast in Armenia, XXV International Congress of Orientalists, Moscow, 1-8: Oriental Literature Publishing House.

Montet P. 1989: Yegipet Ramsesov (Povsednevnaya žizn' yegiptyan vo vremena velikikh faraonov) (Egypt of the Ramseses (Daily life of the Egyptians during the time of the great pharaohs)), Moskva (In Russian).

Muzzio I. 1925: Su di un olio medicato de la tomba di Cha, in: Atti della Societá Linguistica di Scienze e Lettere, № 4, 249-253.

Niggorski A. M. 1999: Polypus and the Poppy: Two Unusual Rhyta from the Mycenean Cemetery at Mochlos, In: Meletemata. Studies in Aegean Archaeology, presented to Malcolm H. Wiener as he enters his 65th year (Ed. by Betancourt P., Karageorgis V., Laffineur R., Niemer W.), Liege, 537-542.

Nikol'skaya K.D., Kločkov I.S., Tomaševič O.V., Tkačenko G.A. 2008: Istoriya i kul'tura Drevnego Vostoka: Entsiklopedičeskiy slovar' (History and Culture of the Ancient Orient: Encyclopedic Dictionary), Moskva (In Russian).

Parrot A. 1958-1959: Mission archéologique de Mari, t. II, Le palais, Bibliothèque archéologique et historique, № 68-70, Paris.

Pasturo M. 2017: Kraski dlya živopisi: lazurit i mednaya lazur'. Siniy. Istoriya tsveta (Colors for painting: lapis lazuli and copper glaze '. Blue. History of color), Moskva (In Russian). https://gemsvalley.ru/lazurit/

Petrossian L., Sandrot J. 1996: Ornament de Char (?): Char á deux Chevaux et Cerf, in: “Arménie: Trésors de l'Arménie Ancienne”, Paris.

Piliposyan A. 1982: Hayastanum haytnabervac' kerinosneri masin, Avandakan žaṙangman hartserə haykakan mšakuyt‘um, Eritasard gitaškhatoğneri V konferans (On Kernoses Found in Armenia, Issues of Traditional Heritage in Armenian Culture, V Conference of Young Researchers), Yerevan, 13-15 (In Armenian).

Piliposyan A. 1994: Art'iki t'iv 107 dambaranits haytnabervac' sakrn u nra hinarevelyan zugahernnerə, «Širaki patmamšakut'ayin žaraangut'yunə», Hanrapetakan arajin gitažoğov, Gyumri (An axe found in Artik Tomb No. 107 and its ancient parallels, "Historical and Cultural Heritage of Shirak", First Republican Conference, Gyumri), 15-16 (In Armenian). 
Piliposyan A. 1998: Haykakan leṙnaškharhi knik'nerə Hin Arevelk'i knik'agorcut'yan hamakargum (The seals of the Armenian Highland in the sealing system of the Ancient Orient), Yerevan (In Armenian).

Piliposyan A. 2000: Hayastani hinarevelyan knik'nerə vorpes Merdzavor Arevelk'i razmak'ağak'akan p'okharnčcut'yunneri skzbnağbyur, «Haykakan k'ağak'akrt'ut'yunə hnaguyn žamanaknerits minčev k'ristoneut'yan əndunumə», gitažoğvi zekutsman t'ezer (Ancient Seals of Armenia as a source of militarypolitical interactions in the Middle East, "Armenian Civilization from Ancient times to the adoption of Christianity", Conference Report theses), Yerevan, 43-44 (In Armenian).

Piliposyan A. 2007: Vosku fenomenə Hayastanum, «Hin Hayastani voskin» (The phenomenon of gold in Armenia, "Gold of Ancient Armenia), Yerevan (In Armenian).

Piliposyan A. 2010: Merdzavor Arevelk'i hin k'ağak'akrt'ut'yunnerə ev Haykakan leṙnaškharhə (mšakut'c'agman ev azgac'agman himnakhndirneri šurj), "K'ağak'agitut'yan hartser - 2009 (hasarakut'yun, patmut'yun, k'ağak'akrt'ut'yun», mijbuhakan gitažoğvi nyut'er (Ancient Civilizations of the Middle East and the Armenian Highland (on the Problems of Culture and Ethnicity), "Issues of Civilization - 2009 (Society, History, Civilization"), Proceedings of the Interuniversity Conference,), Yerevan, 203-222 (In Armenian).

Piliposyan A. 2014: Mec'amori sardonik'se kšřak'arə' gorti khorhrdanšakan paštamunk'i ararka («B. B. Piotrovskin ev hnagitut'yunə» gitakan hodvac'neri žoğovac'u) (The sardonic scale of Metsamor as a subject of the symbolic cult of the frog ("V.V. Piotrovsky and Archeology" collection of scientific articles),), Yerevan, 100-107 (In Armenian).

Piliposyan A. 2015: Mec'amori knik'nerə, «Mec'amor. Kesdarya peğumneri taregrut'yun» mijazgayin gitažoğovi hodvac'neri žoğovac'u nvirvac' Mec'amor hnavayri peğumneri 50 ev argelots-t'angarani steğc'man 45 amyaknerin (The seals of Metsamor, "Metsamor. Chronicle of half a century of excavations "International conference collection of articles dedicated to the 50th anniversary of the excavations of archaeological site Metsamor and 45th anniversary of the foundation of the Reserve-museum), Yerevan (In Armenian).

Piliposyan A. 2018: Tesaranayin horinvac'k'nerov hinmerdzavorarevelyan ev mijerkrac'ovyan glanadzev knik'nern u drants art'ikyan zugahernerə, "Aragac'i t'ikunk'um». Hnagitakan hetazotut'yunner nvirvac' Telemak Khačatryani hišatakin (The ancient "Mediterranean cylinders" with their scenic compositions and their 
articulated parallels, "Behind Aragats". Archaeological excavations dedicated to the memory of Telemak Khachatryan), Yerevan, 114-125 (In Armenian).

Piliposyan A., Badalyan R. 2007: Hoŕom, "Hin Hayastani voskin» (Horom, "Ancient gold of Armenia), Yerevan, 130-133 (In Armenian).

Piliposyan A., Gevorgyan L., Abgaryan A., Zak'yan A. 2015: Mec'amor (Patmahnagitakan aknark) (Metsamor (Historical-archeological review)), Yerevan (In Armenian).

Piliposyan A., Zak'yan A. Gevorgyan L., Poğosyan D. 2013: Mec'amori voskin, «Mec'amori» patmahnagitakan argelots-t'angarani hatuk uğetsuyts (The Metsamor's Gold, a special guide to the Metsamor Historical-Archaeological Reserve-Museum) (In Armenian).

Piliposyan A., Hovhannisyan V. 2003: Art'iki t‘iv 422 dambarani mitannakan knik‘ə, «Hayastani hnaguyn mškuyt‘ə», № 3 (Telemak Khačatryani 70-amyakin nvirvac‘ gitažoğvi nyut'er) (The mystical seal of Artik tomb No. 422, "The ancient culture of Armenia", № 3 (materials of the conference dedicated to the 70th anniversary of Telemak Khachatryan),), Yerevan, 72-82 (In Armenian).

Piotrovskiy B. B. 1983: Vadi-Allaki - put' k zolotym rudnikam Nubii (Drevneyegipetskiye naskal'nyye nadpisi: Rezul'taty rabot arkheologičeskoy ekspeditsii AN SSSR v Yegipetskoy arabskoy respublike 1961-1962, 1962-1963 gg.) (Vadi-Allaki - the way to the gold mines of Nubia (Ancient Egyptian rock inscriptions: Results of the work of the AS USSR archaeological expedition in Arab Republic of Egypt in 1961-1962, 1962-1963),), Moskva (In Russian).

Podosyonov S. 2020: Gipnos, Morfey i Tanatos. Istoriya opiuma ot Drevnego Yegipta do kolonial'nykh voyn (Hypnos, Morpheus and Thanatos. The history of opium from Ancient Egypt to the colonial wars), https://knife.media/ancient-opiates/ (In Russian).

Rosso A. M. 2010: Poppy and Opium in Ancient Times: Remedy or Narcotic? A Multidisciplinary Peer-Reviewed Journal “Biomedicine International”, № 1, 81-87.

Salavert A., A. Zazzo, L. Martin, F. Antolín, C. Gauthier, F. Thil, O. Tombret, L. Bouby, C. Manen, M. Mineo, A. Mueller-Bieniek, R. Piqué, M. Rottoli, N. Rovira, F. Toulemonde, I. Vostrovská 2020: Direct Dating Reveals the Early History of Opium Poppy in Western Europe, "Scientifc Reports", 10:20263. https://doi.org/10.1038/s41598-020-76924-3

Saleh M., Sourouzian H. 2007: Official Catalogue the Egyptian Museum, Cairo, Mainz.

Saggs H. 1968: The Tell Al Rimah Tablets, Iraq, vol. XXX, pt. 2, 154-174. 
Sakellarakis J. A. 1987: Herakleion Museum. Illustrated guide to the Museum. Ekdotike Athinon, Athens.

Salvini M. 1996: Geschichte und Kultur der Urartäer, Darmstadt: Wissenschaftliche Buchgesellschaft.

Saporetti C. 1970: Onomastica Medio - Assira, t. 1, Roma.

Šanšašvili N., Narimanišvili G. 2014: K izučeniyu bronzovykh štandartov Yužnogo Kavkaza serediny II tys. do n.e. (To the study of the bronze standards of the South Caucasus in the middle of the 2nd millennium BC,), Yerevan (In Russian).

Šanšašvili N., Narimanišvili G., Narimanishvili Ga. 2016: Torgovlya i torgovyye puti meždu Yužnym Kavkazom i Bližnim Vostokom (3-2 tysyačeletiyakh do n.e.) (Trade and trade routes between the South Caucasus and the Middle East (3-2 millennia BC),), 99-161, Tbilisi (In Russian).

Thompson R. C. 1924: Assyrian Herbal, London.

Tomashevska M. 2019: Sacred Floral Garlands and Collars from the New Kingdom Period and Early Third Intermediate Period in Ancient Egypt. 1550 BC - 943 BC. Master Thesis Classics and Ancient Civilizations, Faculty of Humanities, Leiden University, Egyptology, S2118564, Leiden (August), 43-44. https://www.researchgate.net/publication/337547952

Tour Egypt 2017: Bracelets from the tomb of Djer. http://www.touregypt.net/featurestories/picture 05182004.htm

Tsakanyan R. 2017: «Tun T'orgoma»-n skzbnağbyurnerum, (The "House of Torgom” in Written Sources, Oriental Studies in Armenia, Vol. 3), Arevelagitut'yunə Hayastanum, № 3, Hin ev Mijnadaryan Hayastanə ev ir harevannerə, Yerevan, 161180 (In Armenian).

Tschirch A. 1923: Handbuch der Pharmakognisie, vol. III, pt. I, Leipzig. https://onlinelibrary.wiley.com/doi/abs/10.1002/jps.3080130226

Vandersleyen C. 1971: Les guerres d'Amosis, fondateur de la XVIIle dynastie. Monographies Reine Élisabeth 1. Brussels. Fondation Égyptologique Reine Élisabeth.

Vinogradova N., Kaptereva T., Starodub T. 1997: Traditsionnoye iskusstvo Vostoka. Terminologičeskiy slovar (Traditional Culture of Orient), Terminological dictionary, Moskva (In Russian).

Yakobson V. 1989: Mesopotamiya v XVI-XI vv. do n.e. v kn. «Istoriya Drevnego Mira. Rannyaya drevnost'» (Mesopotamia in XVI-XI cc. BC in "History of Ancient World") (Ed. by I. M. D'yakonov, D. V. Neronova and I. S. Sventsitskaya), Moskva (In Russian). 
Yesayan S. A. 1966: Oružiye i voyennoye delo drevney Armenii (III-I tys. do n. e.) (Weapons and military affairs of Ancient Armenia), Yerevan (In Russian).

Yesayan S. A. 1980: Skul'ptura Drevney Armenii (Sculpture of Ancient Armenia), Yerevan (In Russian).

Yesayan S., Mnatsakanyan A. 1975: O statuetkakh Lčašena (About the statuettes of Lchashen), Historical-Philological Journal, № 2, Yerevan, 253-261 (In Russian).

Wilkinson A. 1998: The Garden in Ancient Egypt, London: Rubicon Press.

Wilson H. 2015: Poppies for remembrance, Ancient Egypt Magazine, vol. 16, № 2, London.

Wiseman D. 1968: The Tell al-Rimah Tablets, 1966, Iraq, vol. XXX, part 2, 175-205.

Woolley L. 1934: Ur Excavations, vol. II, The Royal Cemetery: a report on the Predynastic and Sargonid graves excavated between 1926 and 1931, LondonPhiladelphia.

Zabkar L.V. 1968: A Study of the Ba Concept in Ancient Egyptian Texts, Chicago, 7389 (Studies in Ancient Oriental Civilization, № 34).

Zak'yan T., Mamikonyan N., Simonyan A. 2020: Hnagitakan ararkaneri verakangnum (Restoration of archeological objects), Yerevan (In Armenian).

Žyul'yen Š.-A. 1961: Istoriya Severnoy Afriki: Tunis, Alžir, Marokko, t. 1. Ot drevneyšikh vremon do arabskogo zavoyevaniya (647 g.) (History of North Africa: Tunisia, Algeria, Morocco, vol. 1, From ancient times to the Arab conquest), Moskva (In Russian).

Zin'kina YU.V., Il'in I.V., Andreyev A.I., Aleškovskiy I.A., Korotayev A.V. 2017: Istoricheskaya globalistika, (Historical globalistics) t. 1, Moskva (In Russian).

\section{Abbreviations}

IDV I 1983: Istoriya Drevnego Vostoka I: Zaroždeniye drevneyšikh klassovykh obšestv i pervyye očagi rabovladel'českoy tsivilizatsii, ch. 1 (pod. red. I.M. D'yakonova) (The History of Ancient Orient I: The birth of Ancient class societies and the first centers of a slave-owning civilization, p. 1, ed. I.M. Dyakonov) Moskva (In Russian).

IDV II 1988: Istoriya Drevnego Vostoka: Zaroždeniye drevneyšikh klassovykh obšestv i pervyye očagi rabovladel'českoy tsivilizatsii, ch. 2 (pod. red. G. M. Bongard-Levina) (The History of Ancient Orient I: The birth of Ancient class societies and the first centers of a slave-owning civilization, ed. G. M. BongardLevin), Moskva (In Russian). 
Ashot Piliposyan

Kh. Abovyan Armenian State Pedagogical University piliposyan@yahoo.com

Armine Hayrapetyan “Erebuni” Historical and Archaeological Museum-Reserve hay_armine@yahoo.com

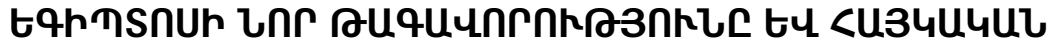

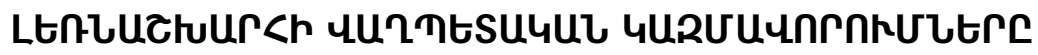

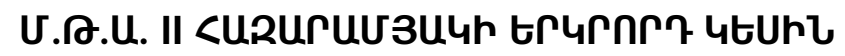

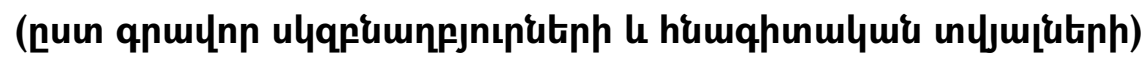

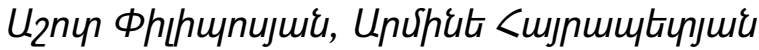

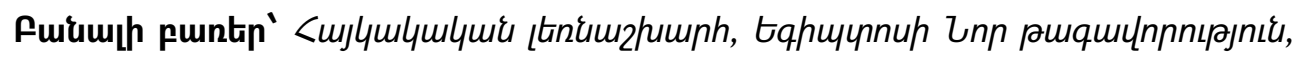

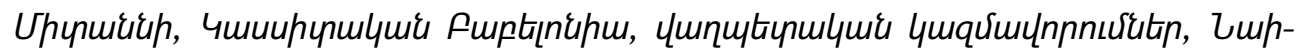

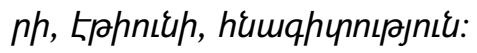

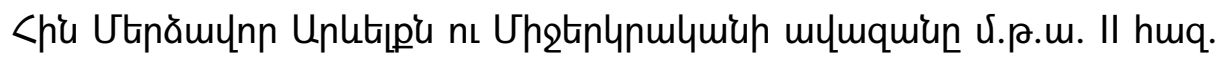

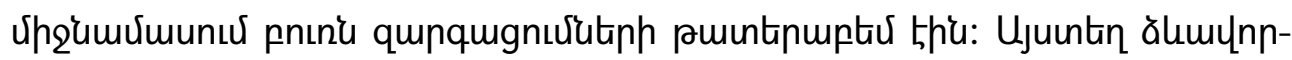

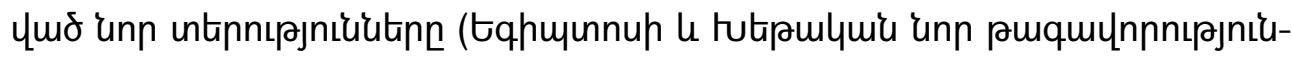

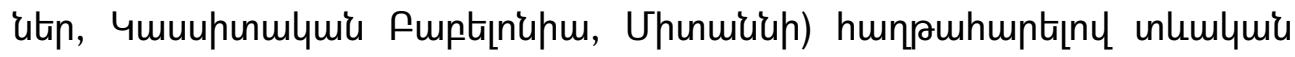

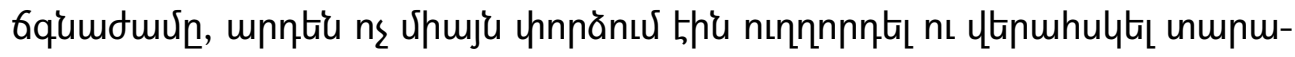

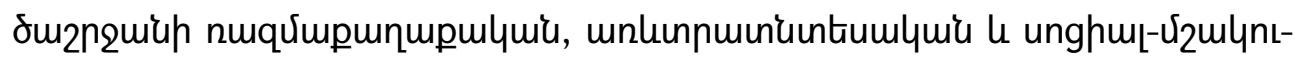

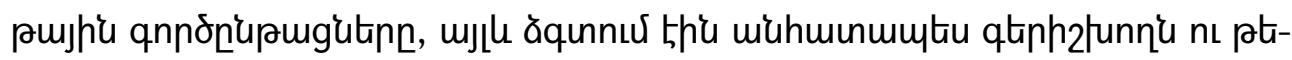

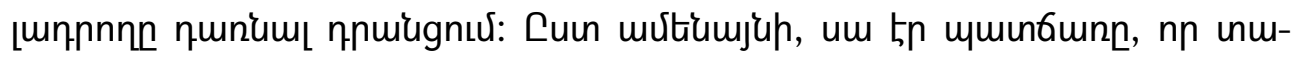

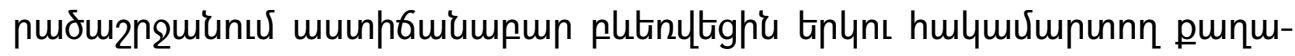

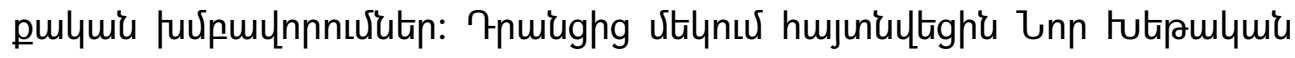

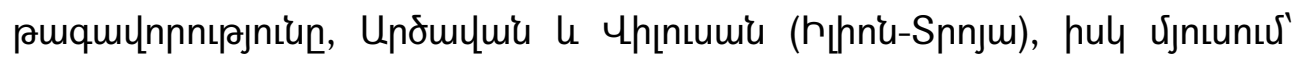

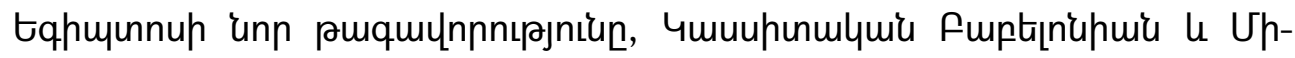
unuiuuhe (Luhumpium):

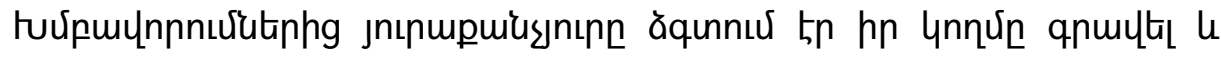

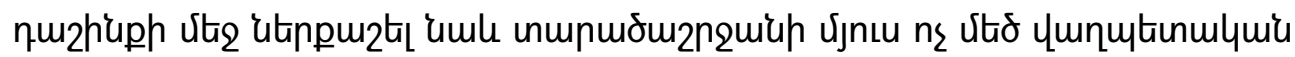




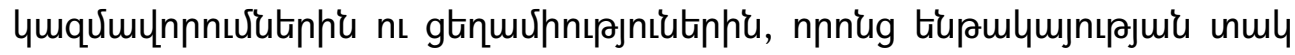

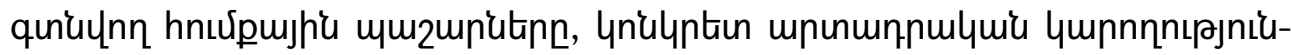

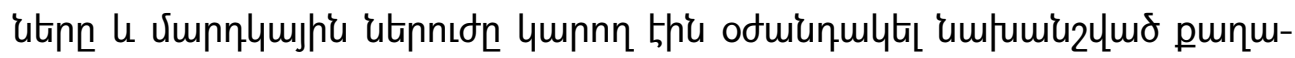

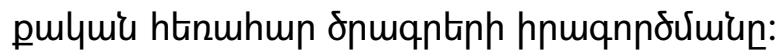

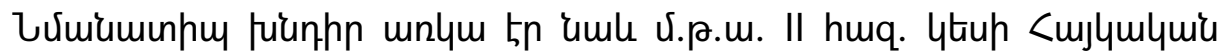

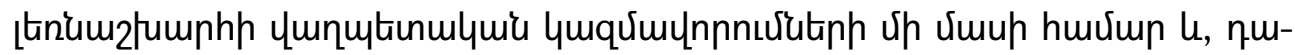

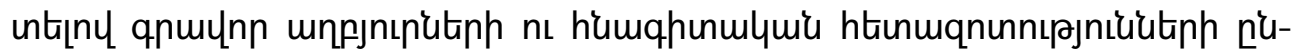

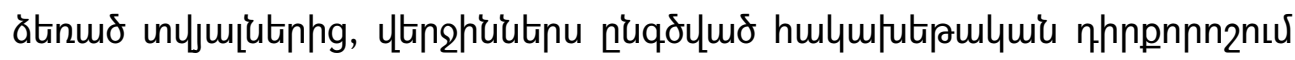

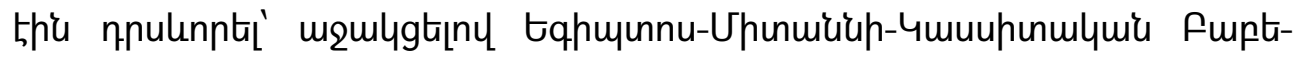

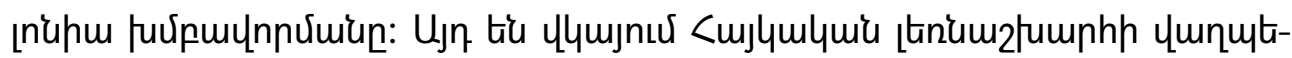

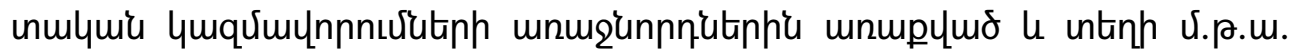

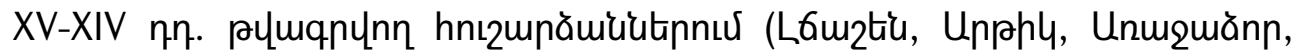

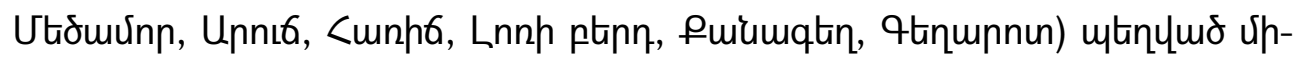

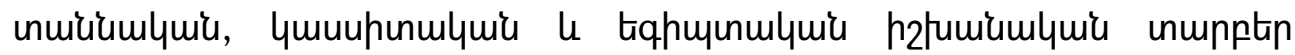
junnhnnuizeuiututnn:

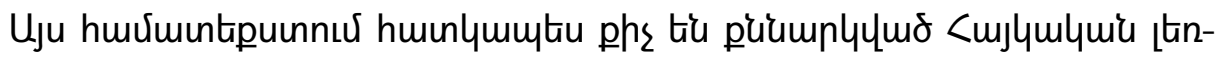

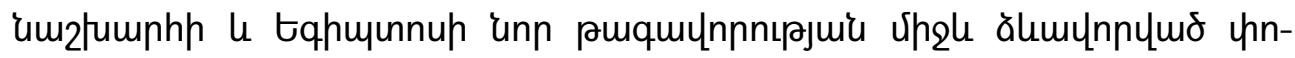

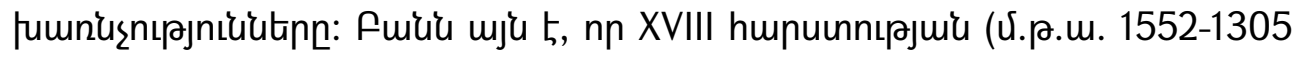

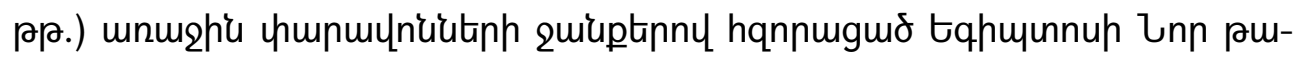

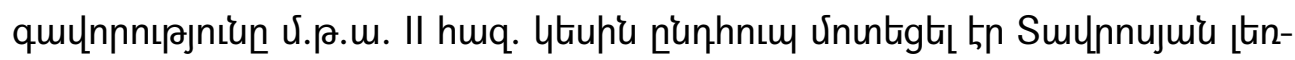

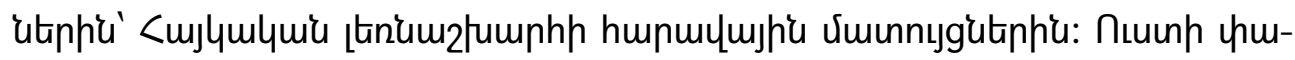

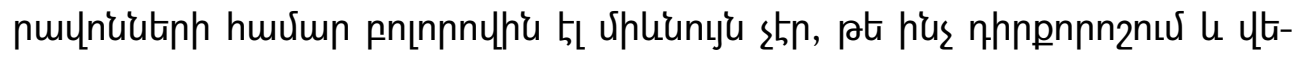

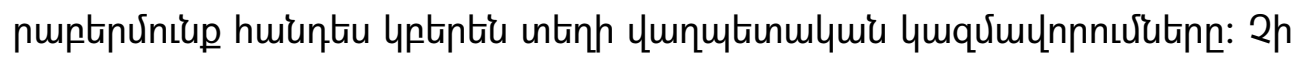

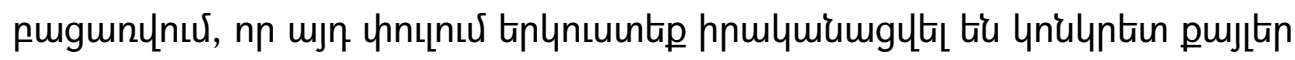

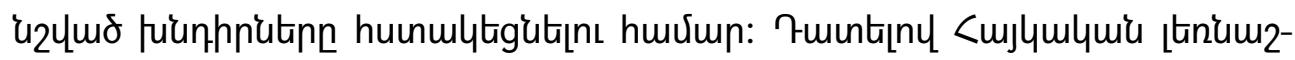

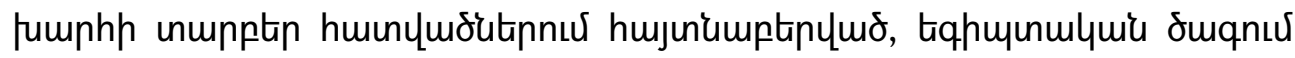

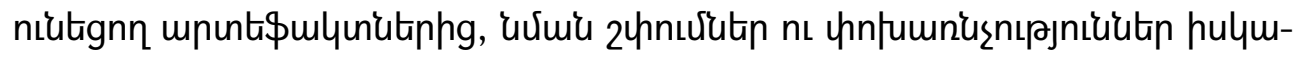

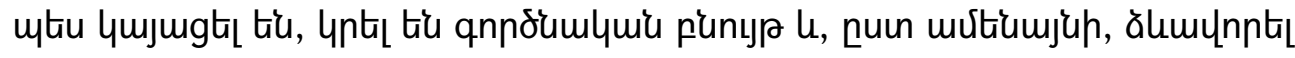

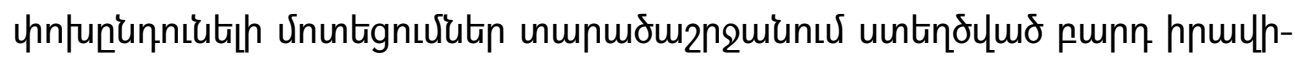
Gulyh hungnus:

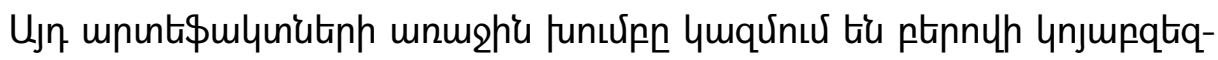

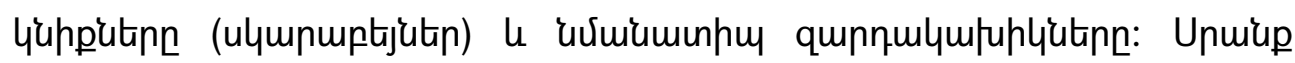




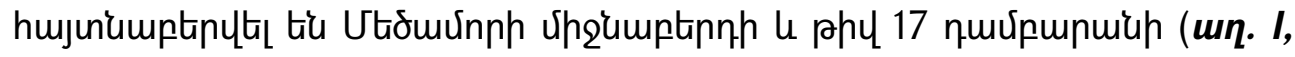

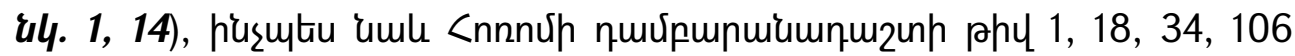

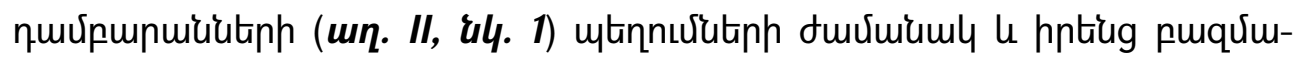

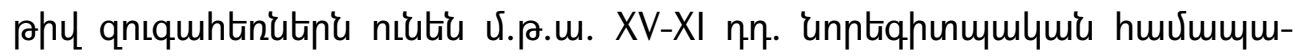

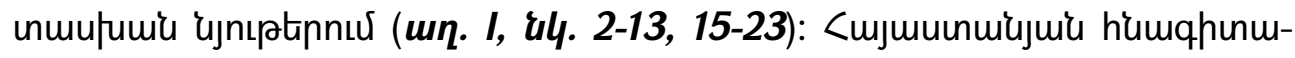

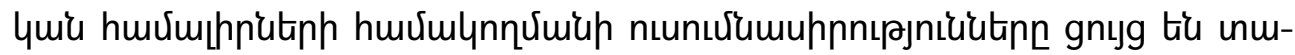

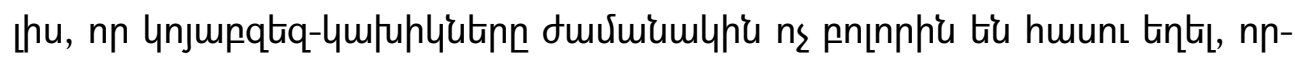

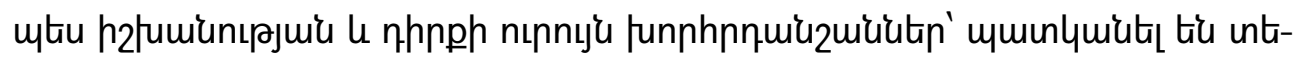

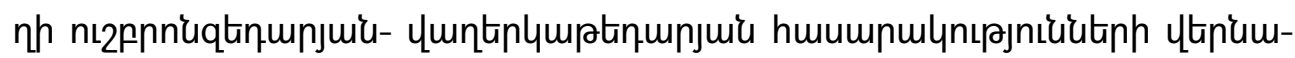

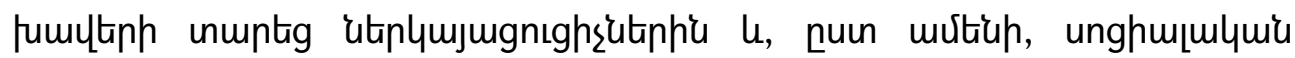

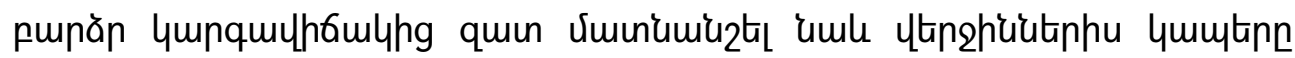

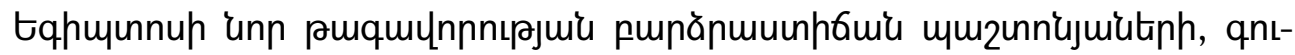
gtil' unpniuhph htiun:

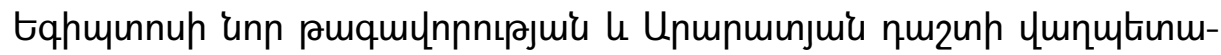

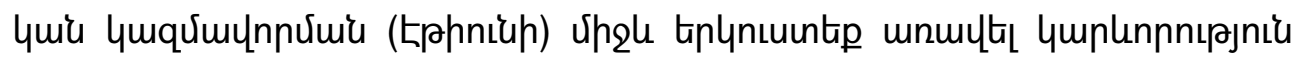

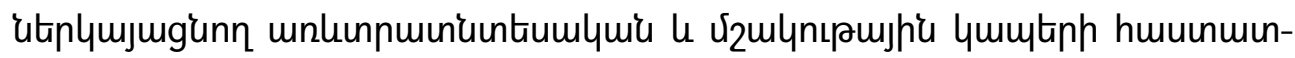

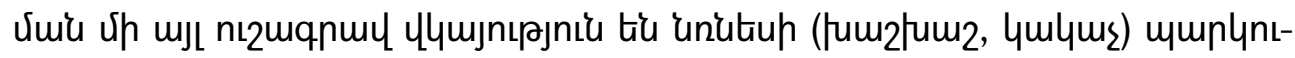

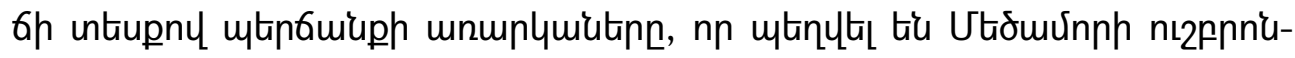

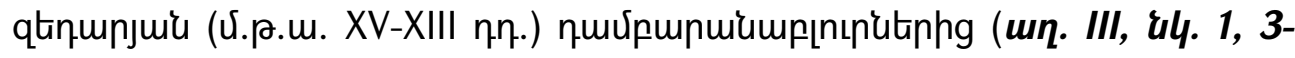

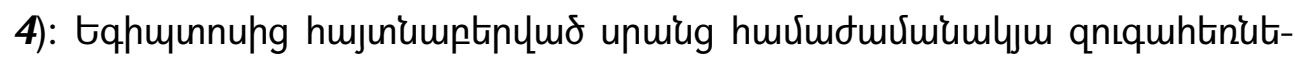

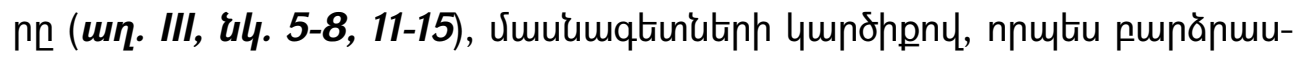

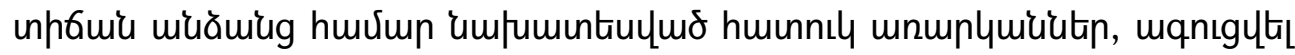

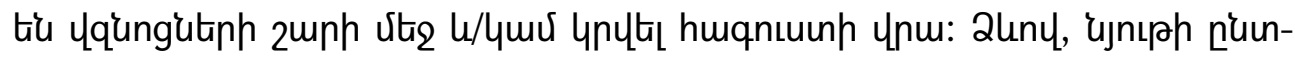

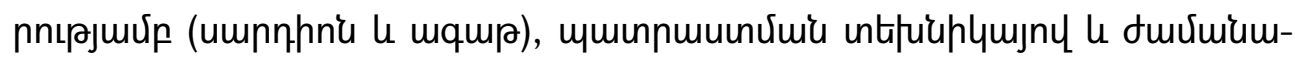

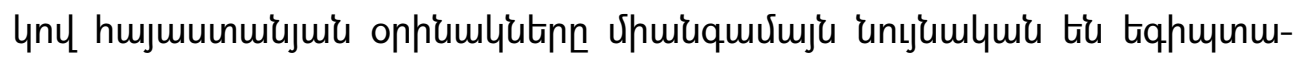

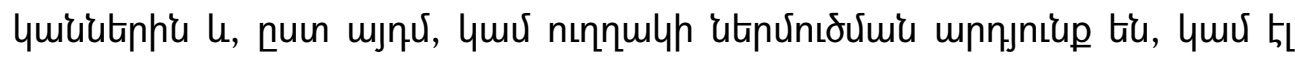

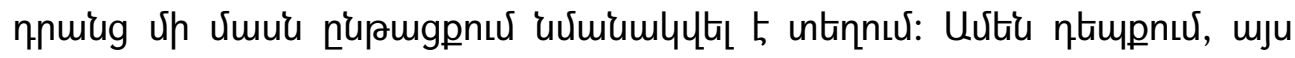

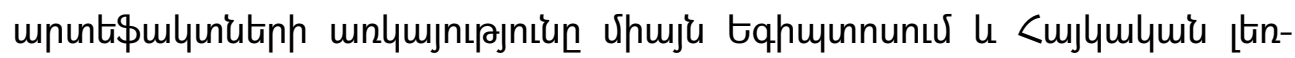

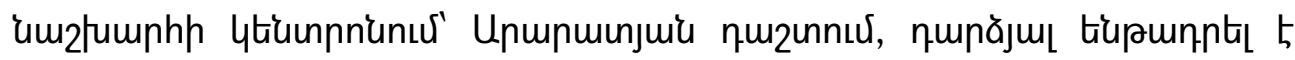

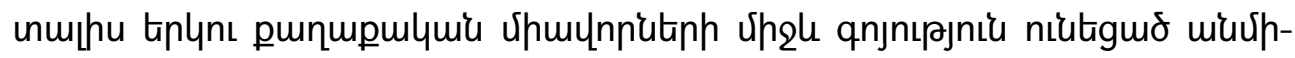

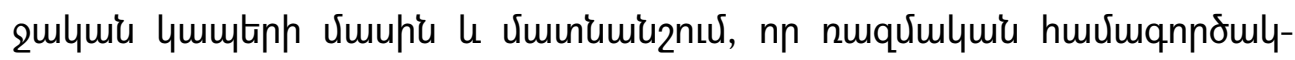




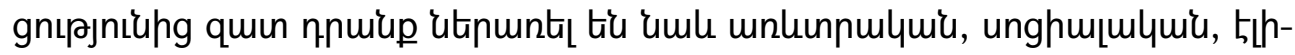
unum le uJL nцnnunitin:

tqhưnnuh unn puquц

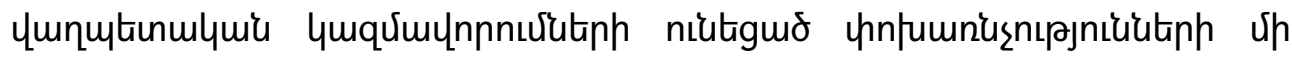

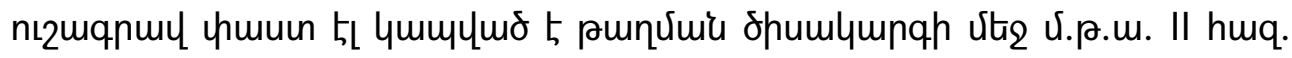

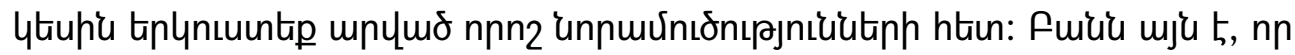

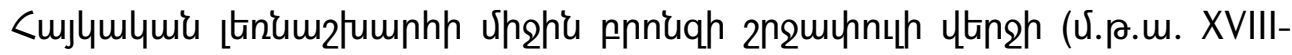

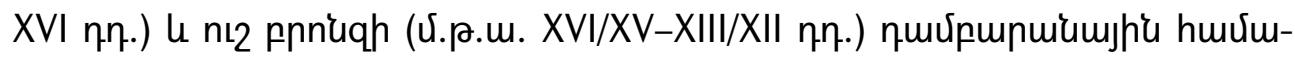

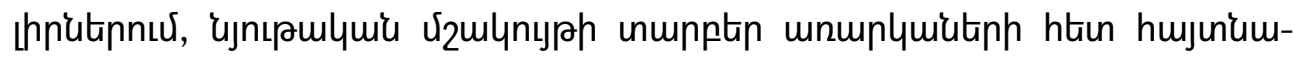

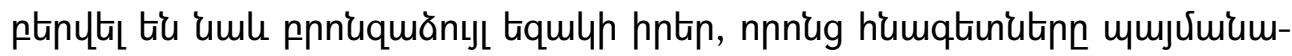

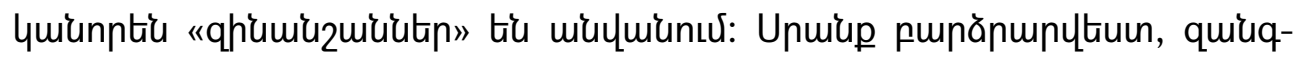

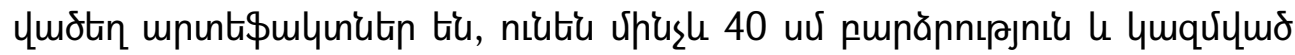

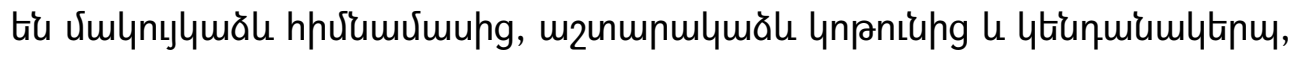

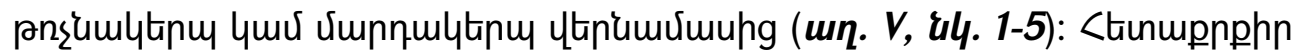

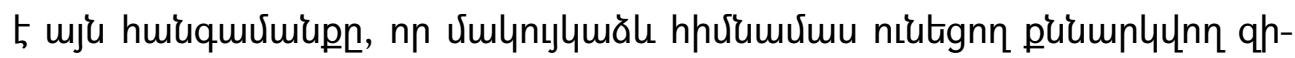

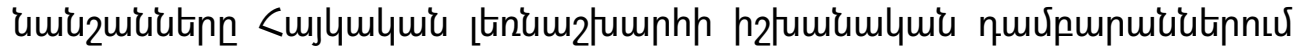

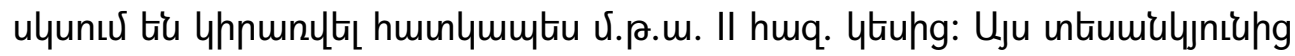

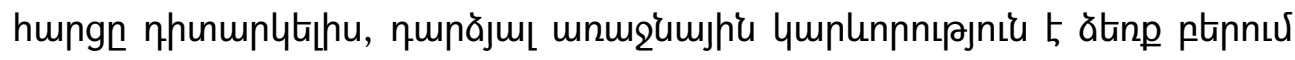

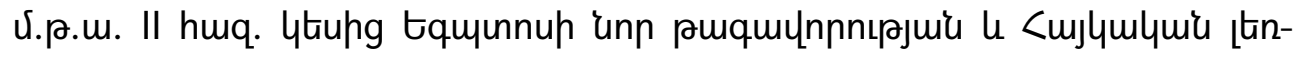

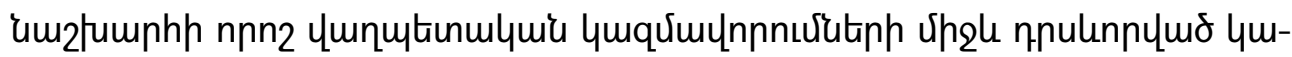

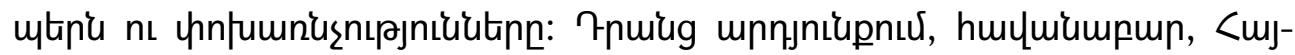

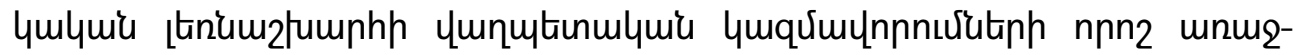

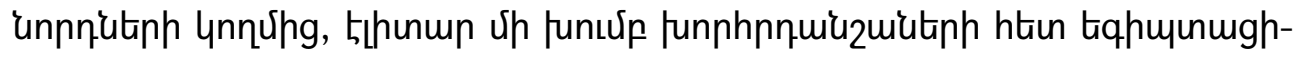

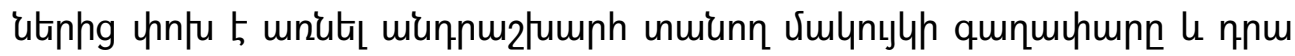

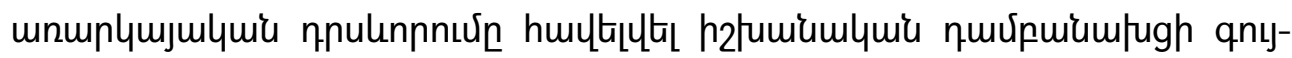

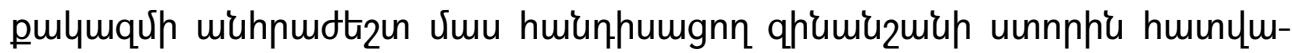

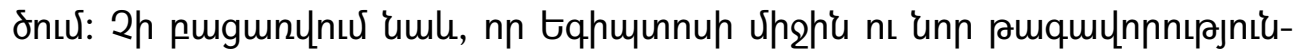

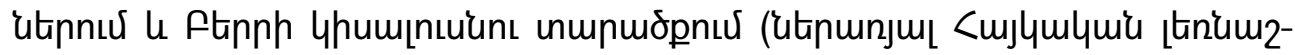

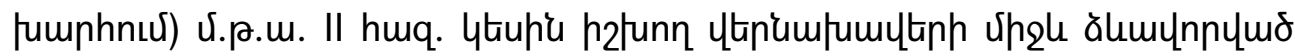

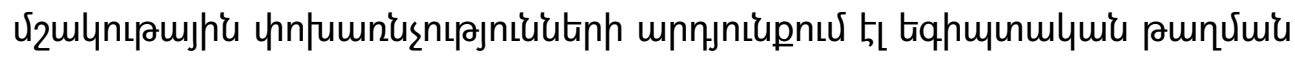

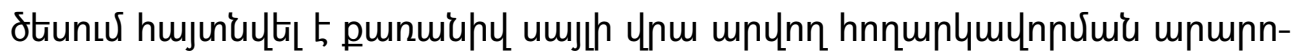

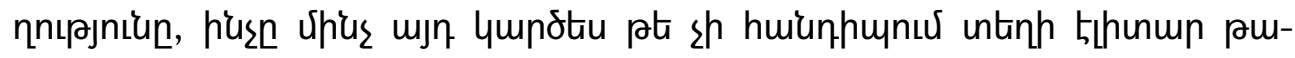




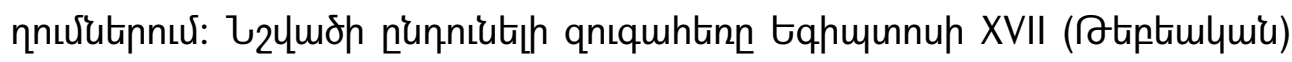

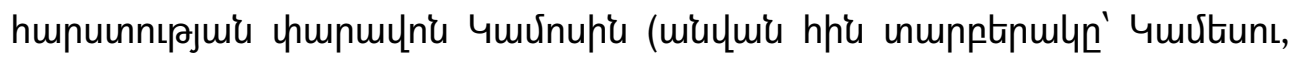

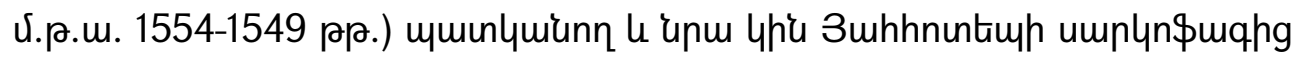

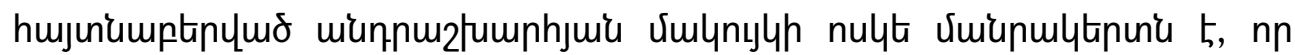

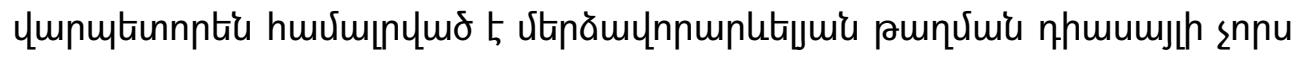
wiuhulutinny (un. V, \&ly. 11):

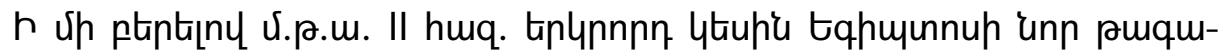

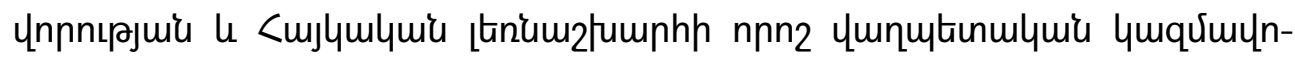

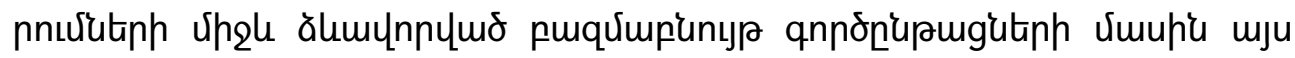

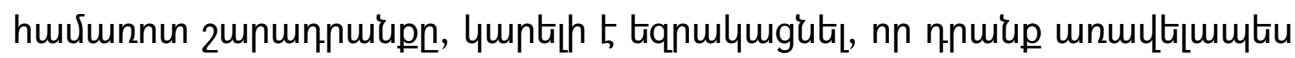

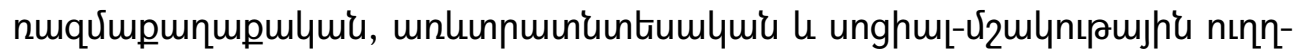

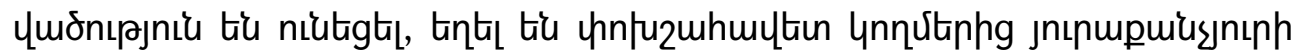

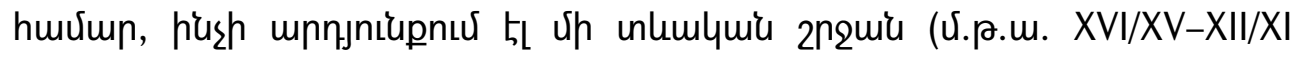

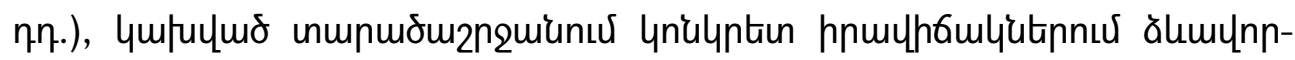

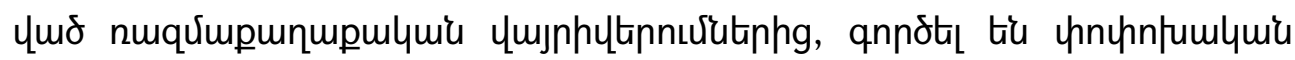

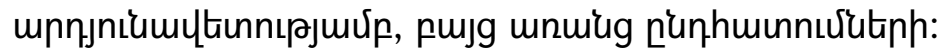

